\title{
Garbage can theory and Australia's National Electricity Market: decarbonisation in a hostile policy environment
}

\author{
Paul Simshauser * \\ Griffith Business School \\ September 2017
}

\begin{abstract}
After two decades of consistent economic and technical performance, conditions in Australia's National Electricity Market (NEM) deteriorated sharply in 2016/17. Prices more than doubled on the east coast, tripled in South Australia (SA), and the SA regional grid collapsed. Nothing spectacular occurred with final demand-this was a supply-side crisis driven by the exit of 18\% of Australia's coal-fired generation fleet and the inadequate entry of new plant. Australia's NEM encountered an exit-driven episode of the Resource Adequacy problem. In the USA where 18\% of coal plant has also exited, Resource Adequacy and low cost energy has been maintained by the entry of an enormous fleet of wind, solar and gas-fired generators. In Australia, an equivalent response did not occur; decades of climate change policy ineptitude meant the speed of coal plant exit was unpredictable, entry of renewables was delayed through policy discontinuity and gas-fired plant was subject to critical hold-up due to excess LNG plant investment. Resolution requires a united and stable climate change policy architecture that works with, not against, the NEM's world-class institutional design.
\end{abstract}

Keywords: Resource Adequacy, Climate Change Policy, Garbage Can Theory.

\section{Introduction}

Australia's National Electricity Market (NEM) ${ }^{1}$ is world-renowned for its consistent economic and technical performance under a wide range of market and operating conditions over two decades (Price, 2017; Simshauser, 2014). However, in 2016/17 NEM conditions deteriorated sharply. Electricity futures for 2018 delivery more than doubled to $\$ 89 / \mathrm{MWh}^{2}$ ( $c f$. long run average spot price of $\$ 42.50 / \mathrm{MWh}^{3}$ ) and on 28 September 2016 the South Australian region of the NEM collapsed - Australia's first black system event since 1964. Moreover, the gas market has become unstable and is transmitting structural damage to the NEM through the crucial role that gas-fired generation plays.

By 2016/17 two decades of climate change policy ineptitude and a distinct lack of purpose vis-àvis gas market policy had finally taken its toll on the NEM. With a climate change policy vacuum the speed of coal plant exit became increasingly unpredictable and generation plant entry in crucial segments had been delayed (renewables) or distorted (gas). Ironically, only a few years earlier academic literature focused on coal plant barriers to exit in the NEM rather than the rapid and unpredictable pace of exit (see Nelson, Reid \& McNeill, 2015; Jotzo \& Mazouz, 2015). The outcome is Australia's electricity and gas markets are now operating more like wrecking balls through the economy rather than markets that help drive economic growth and enhance welfare.

Climate change policy is frequently mobilised through various carbon pricing policy mechanisms. This occurs across a wide range of OECD/G20 countries (Nong \& Siriwardana, 2017). ${ }^{4}$ But at

\footnotetext{
* Views expressed in this article are those of the author.

${ }^{1}$ The NEM comprises Queensland (QLD), New South Wales (NSW), Victoria (VIC), South Australia (SA), Tasmania and the Australian Capital Territory (ACT). ACT forms part of the NSW region. Western Australia and Northern Territory are too remote.

${ }^{2}$ In Sep17 electricity futures were $\$ 95$ (NSW), \$81 (QLD), \$118 (SA) and \$107 (VIC) with a NEM weighted average of \$89/MWh

${ }^{3}$ NEM weighted-average spot prices from FY2005-2017, expressed in constant 2017 dollars.

${ }^{4}$ Nong \& Siriwardana (2017) note this includes EU27 plus Switzerland, Iceland, Norway, New Zealand, South Korea and Kazakhstan.

The US states of Connecticut, Delaware, Maine, Maryland, Massachusetts, New Hampshire, New York, Rhode Island, Vermont
} 
least two countries appear to find this exceedingly difficult to achieve at the national level; the USA (Schelly, 2014) and Australia (Nelson, 2015). ${ }^{5}$ To generalise, both countries have social democratic parties that support carbon pricing and greater use of renewables, and conservative parties that do not have a unified position, and therefore do not. Both countries have vast fossil fuel reserves that have provided a source of international comparative advantage. Some policymakers argue the introduction of carbon pricing and related policy instruments (e.g. Renewable Energy Targets involving taxpayer subsidies) will damage this advantage (MacGill, 2010; Simshauser, 2011, Byrnes et al 2013; Jones, 2014; Nelson et al. 2015; Jaraites et al. 2017).

Australia was a signatory to the Kyoto Protocol and to the Paris Agreement with bipartisan political support. ${ }^{6}$ Energy utilities and investors anticipate a conventional policy cycle incorporating distinct stages, viz. a rational policy development process guided by a professional public service, a meaningful industry consultation process coupled with the rationality of applied economic problem solving supported by extensive quantitative analysis (given the complexity of power markets) in which to generate sound public policy advice. Advice is prosecuted within the government's agenda and after negotiating within the bounds of reasonable political constraint, relevant policy is legislated and enters into force. For a market-based power system like the NEM to function properly, investor knowledge, expectation and conviction must ultimately match policy settings and policy intent; and vice versa.

But it would be naive for energy industry participants to believe climate change policy development follows a conventional cycle in Australia after two decades of policy discontinuity. Much closer to the mark is Garbage Can Theory of policy development, a model extracted by

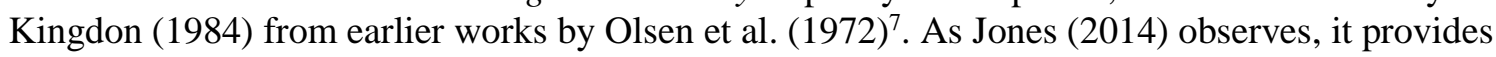
a helpful interpretation of the operating environment that energy utilities and their investors face in Australia.

At its core, Garbage Can Theory rejects the notion that policymaking follows a conventional or methodological process; policymaking is thought to be chaotic, fragmented, random, contingent and frequently "arational" (Tiernan \& Burke, 2002). In the model, as policies are developed they frequently fail to make the congested political schedule, and so are dumped in a garbage can, thus becoming part of an accumulating set of policy solutions in search of a problem (see Olsen et al. 1972). To be revived, discarded policy solutions require suitable problem definition (Peters, 2002), a political window prised open to create an opportunity for deployment (Howlett et al. 2014; Jones 2014) and a policy entrepreneur to build acceptance and synchronise all three elements, viz. problem definition, policy solution and the political window of opportunity (Tiernan \& Burke, 2002). A focusing event is typically required to catalyse problem definition and prise open the political window of opportunity (see Kingdon, 1995; Birkland, 1998). Indeed, the essential element of Garbage Can Theory is agenda-setting; for a policy solution to land it must make its way to the top of a very congested political schedule spanning health, education, defence, housing and so on; consequently all three conditions, viz. problem definition, policy solution and the political window of opportunity, need to be simultaneously satisfied (Kingdon, 1995; Birkland 1998; Peters, 2002; Tiernan \& Burke, 2002; Howlett et al 2014; Jones, 2014; Rawat \& Morris, 2016).

In the present environment, Australia's energy and climate change policy garbage can contained a decade-old policy solution still in search of a problem; a Clean Energy Target mechanism

operate a carbon pricing schemes. California along with Québec and Ontario have a joint scheme. China launched its ETS at the end of 2017.

${ }^{5}$ Jones (2014) highlights that Canada faces similar issues.

${ }^{6}$ Under the Kyoto Protocol, Australia agreed to limit $\mathrm{CO}_{2}$ emissions to $108 \%$ of 1990 levels, and the Paris Agreement requires $\mathrm{CO}_{2}$ emissions be limited to 26-28\% below 2005 levels by 2030 .

${ }^{7}$ The core of Olsen et al. (1972) is that when a decision making environment has become complex, and decision options are problematic, technology is unclear, and participation is fluid, these conditions satisfy a 'garbage can' model of governance. 
involving tradable certificates below a $\mathrm{CO}_{2}$ baseline intensity. The collapse of the SA power system, the sudden announcement of Hazelwood power station's closure and the associated doubling of electricity futures prices sparked a focusing event and prised-open a political window of opportunity. A policy entrepreneur was appointed by the Commonwealth energy minister, viz. Australia's Chief Scientist Alan Finkel. The 'Finkel Review' of the NEM's focusing event facilitated problem definition, viz. carbon policy discontinuity and the lack of a credible and united post-2020 energy and climate change policy architecture. A problem emerged, however.

The policy was unable to land; the agenda became cluttered with other policy distractions (viz. 50 recommendations in total) and other policy influential, viz. other well-resourced policy entrepreneurs with counter views on climate change policy, were overlooked. Climate change policy is a contested space, and the window was consequently foreclosed by the counter policy influentials. In the end, 49 of the Finkel Review's 50 recommendations were accepted, and the one that mattered, the Clean Energy Target, was discarded to the garbage can.

Two further problems emerged. First, problem definition was mis-specified. Even if climate policy certainty was delivered tomorrow, it would only partially resolve NEM issues; gyrations in the market for natural gas are, at a minimum, equally responsible for the current crisis. Second, the Clean Energy Target, relegated to the garbage can in 2007, was the wrong policy solution ${ }^{8}$ to the current problem. The Clean Energy Target policy in its original form was designed to initiate a wave of clean technology investment into a coal-dominated power system, up to $15 \%$ market share. As a scheme involving a "side market" of tradable certificates, it was never intended to be applied after the completion of a 20\% Renewable Energy Target (i.e. spanning 20\%-35\% market share).

Certificate schemes like a Clean Energy Target have been demonstrated to work efficiently and effectively in terms of initiating investment (Daly \& Edis, 2010). But as certificate schemes or "side markets" rise in materiality (i.e. greater than $25 \%$ market share) they start to work actively against organised spot electricity markets (see Edenhofer et al. 2013; Helm, 2014; Newbery, 2015; Nelson et al. 2015; Keay, 2016; Pollitt \& Anaya, 2016; Neuhoff et al. 2016; Green \& Staffell, 2016; Simshauser, 2017b). Consequently, a Clean Energy Target following on from a fully subscribed $20 \%$ Renewable Energy Target would necessitate a premature re-design of the NEM during an expansionary investment phase. This is a predictable outcome, unless a Clean Energy Target policy is adopted in name, then heavily modified in application.

The purpose of this article is to review the build-up of Australia's climate change policy garbage can and further refine the problem definition. This article is structured as follows. Section 2 reviews Australian climate change policy literature. Section 3 reviews the consequences of climate change policy discontinuity by contrasting generation plant entry and exit in Australia and the USA. Section 4 introduces the PF Model and produces the evolution of generalised entry costs for new plant along with a comparison to incumbent plant over the 2007-2017 period, and demonstrates why re-investment is a term that will progressively gain traction in mid-term policymaking. Section 5 reviews the gas market. Policy implications and concluding remarks follow.

\footnotetext{
${ }^{8}$ The intent of the Clean Energy Target was to operate as a technology-neutral extension of Australia's Renewable Energy Target. This intent is very clear; "... with the additional context that a Clean Energy Target can be implemented within an already well understood and functioning framework, and has better price outcomes, the Panel recommends a Clean Energy Target be adopted..." (Finkel, 2017, p.97). As Section 2.1 later explains, an unmodified extension of the RET, given known design errors, would almost certainly result in a premature NEM re-design. The Finkel recommendation was issued with a caveat of a 'generator reliability obligation'. Rather than using a market mechanism to deliver minimum dispatchable generation levels, the obligation was to be imposed on individual power projects on a regional basis. See Finkel (2017, Chapter 4).
} 


\section{Review of Australian literature: the climate change policy garbage can}

Australia's NEM has a two-decade history of climate change policy discontinuity (Nelson et al. 2010; Byrne et al 2013; Molyneaux et al 2013; Nelson et al, 2013; Byrne et al. 2013; Freebairn, 2014; Garnaut, 2014; Wagner et al. 2015; Nelson 2015; Apergis \& Lau, 2015). Australia's climate change policymaking cycle can be traced back to 1997 when Australia signed the Kyoto Protocol (Jones, 2009). Policy advice focused on a Renewable Energy Target and an Emissions Trading Scheme (Jones, 2010). ${ }^{9}$

\subsection{Renewable Energy Target}

Australia introduced the world's first renewable energy portfolio standard after initiating policy development in 1997, passing legislation in 2000 and commencing the scheme in 2001 (MacGill, 2010; Buckman \& Diesendorf, 2010; Jones, 2010). The Renewable Energy Target or RET mandated an additional $2 \%$ of energy be produced from renewable sources (Forrest \& MacGill, 2013; Byrne et al 2013; Cludius et al 2014). RET liability was placed on electricity retailers and mobilised by "tradeable certificates" with a non-compliance penalty of \$40/MWh (Jones, 2009; Nelson et al. 2013).

A review of the $2 \%$ RET in 2003 (Tambling Review ${ }^{10}$ ) found the target would be met four years ahead of schedule in 2006 (Buckman \& Diesendorf, 2010; Daly \& Edis, 2010). The Tambling Review recommended extending and expanding the RET but this was rejected by the incumbent conservative commonwealth government (Jones, 2009). Inaction by the commonwealth led to Victoria legislating its own 10\% target, with NSW and SA preparing to follow suit (Nelson et al 2013; Jones 2014; Cludius et al. 2014). Queensland legislated a 15\% Clean Energy Target with 'technology set-asides' (Schelly, 2014) comprising a 13\% Gas Electricity Certificate scheme and a $2 \%$ renewable target (MacGill et al 2006; Nelson et al 2010).

In response, the 2007 Commonwealth election elicited two election commitments from the major parties; the incumbent conservative government committed to a national $15 \%$ Clean Energy Target and the social democratic opposition committed to a greatly expanded $20 \%$ RET by 2020 (Jones, 2010; Nelson et al 2013; Apergis \& Lau, 2015). Following the election, the incoming social democrats legislated the $20 \%$ RET in $2009^{11}$ while the $15 \%$ Clean Energy Target was discarded (Cludius et al. 2014).

The 2\% RET and its associated side market (i.e. certificate market) had trivial impacts on Australia's organised spot markets but expanding the scheme to $20 \%$ without adjustment revealed certain design flaws. The policy lacked in-built mechanisms to reduce incentives over time (Buckman \& Diesendorf, 2010). 'Energy Intensive Trade Exposed' (EITE) industries were treated differentially and were largely excluded from RET cost recovery ${ }^{12}$ - instead RET costs were shifted to residential households and in consequence transient merit-order effects benefited EITE customers disproportionately (see Jones, 2010; Forrest \& MacGill, 2013; Byrne et al 2013; Cludius et al. 2014; Bell et al. 2015). Furthermore, little thought went into the interplay between

\footnotetext{
${ }^{9}$ The Howard Government released a broad climate policy strategy titled "Safeguarding the Future: Australia's Response to Climate Change. On 20 November 1997 Prime Minister Howard announced that the Commonwealth would work with the State Governments to "set a mandatory target for electricity retailers to source an additional two per cent of their electricity from renewable energy sources by 2010 ". In the same speech, the PM stated on emissions trading that "Australia also believes that an international emissions trading regime would help minimise costs of reducing emissions. We would support emissions trading on the basis of a satisfactory initial allocation of emission entitlements and a practical resolution of the administrative difficulties involved." (see Parliament of Australia at: http://parlinfo.aph.gov.au/parlInfo/search/display/display.w3p;query\%3DId\%3A\%22chamber\%2Fhansardr\%2F1997-1120\%2F0016\%22 - accessed August 2017).

${ }^{10}$ See Tambling Review at

http://parlinfo.aph.gov.au/parlInfo/search/display/display.w3p;query=Id\%3A\%22library\%2Flcatalog\%2F00122747\%22

${ }^{11}$ The legislation was the Renewable Energy (Electricity) Amendment Act 2009. Around the same time, the Renewable Energy

Directive (mandating the EU15 achieve 20\% renewable energy production by 2020) also entered into force (see Jaraite et al 2017).

${ }^{12}$ Energy intensive customers from mining and manufacturing were shielded from the cost of the RET with $90 \%$ and $60 \%$ exemptions. See Byrne et al (2013) or Buckman \& Diesendorf (2010).
} 
renewable certificate prices and negative spot prices ${ }^{13}$ or the provision of Frequency Control Ancillary Services and consequently no VRE generator in Australia provides system stability services (MacGill, 2010; Bunn \& Yusupov, 2015; Simshauser, 2017b). Compounding matters, two-yearly reviews of the $20 \%$ RET, ironically negotiated by the Greens, produced a stop-start investment cycle centred around the timing of legislated biannual policy reviews. But perhaps the most destructive design error, which eventually led to a policy intervention, was absence of technology set-asides for small-scale solar PV.

The nominal output of small-scale solar PV was "deemed" for 15 years in advance and certified in the year of installation (to reduce transaction costs). This enabled 15 years of certificates to be created in year 1. Furthermore, a Rooftop Solar Multiplier of 5x was added to accelerate technology adoption. The combination of "deeming" and the "Multiplier" meant 75-years of Renewable Energy Certificates were created in the year a rooftop solar PV unit was installed (i.e. $5 \mathrm{x}$ Multiplier, 15 years deemed output). The certificates, colloquially referred to as "Phantom RECs" in the literature, flooded the market and destabilised the RET policy (see Buckman \& Diesendorf, 2010; Cludius et al 2014). Phantom RECs resulted in the RET being annexed into small and large scale RET policies in June 2010 (Nelson et al 2013; Byrne et al. 2013; Nelson 2015).

Following the 2013 election, the new conservative government initiated another review of the RET ('Warburton Review'). With electricity demand contracting for the first time in 121 years, the $20 \%$ RET - which was initially expressed as a fixed $45,000 \mathrm{GWh}$ target but reduced to $41000 \mathrm{GWh}$ following the Phantom REC annexure of small-scale renewables - was looking more like a 25-30\% Target (Nelson et al. 2013; Byrne et al. 2013). The Warburton Review focused on the policy effects, viz. forcing more intermittent capacity into an increasingly oversupplied and unstable wholesale electricity market while associated REC certificate costs were levied on consumers (at the retail level). This was occurring at a time when residential electricity tariffs and network charges in particular were rising sharply (Simshauser et al. 2011; Cludius et al. 2014; Garnaut, 2014; Nelson et al. 2015; Bell et al. 2017). The RET was once again fundamentally altered - scaled back from 41000GWh to 33000GWh in mid-2015 (Biggs, 2016). As Figure 1 illustrates, policy decisions and political events were frequent drivers of non-trivial REC price changes (Buckman \& Diesendorf, 2010; Nelson et al 2013; Cludius et al 2014; Nelson, 2015; Nelson et al. 2015).

${ }^{13}$ Bunn \& Yusupov (2015) note negative prices occur in Australia, North America, Germany, Denmark and Spain. 
Figure 1: $\quad$ REC Spot Prices (2001-2017)

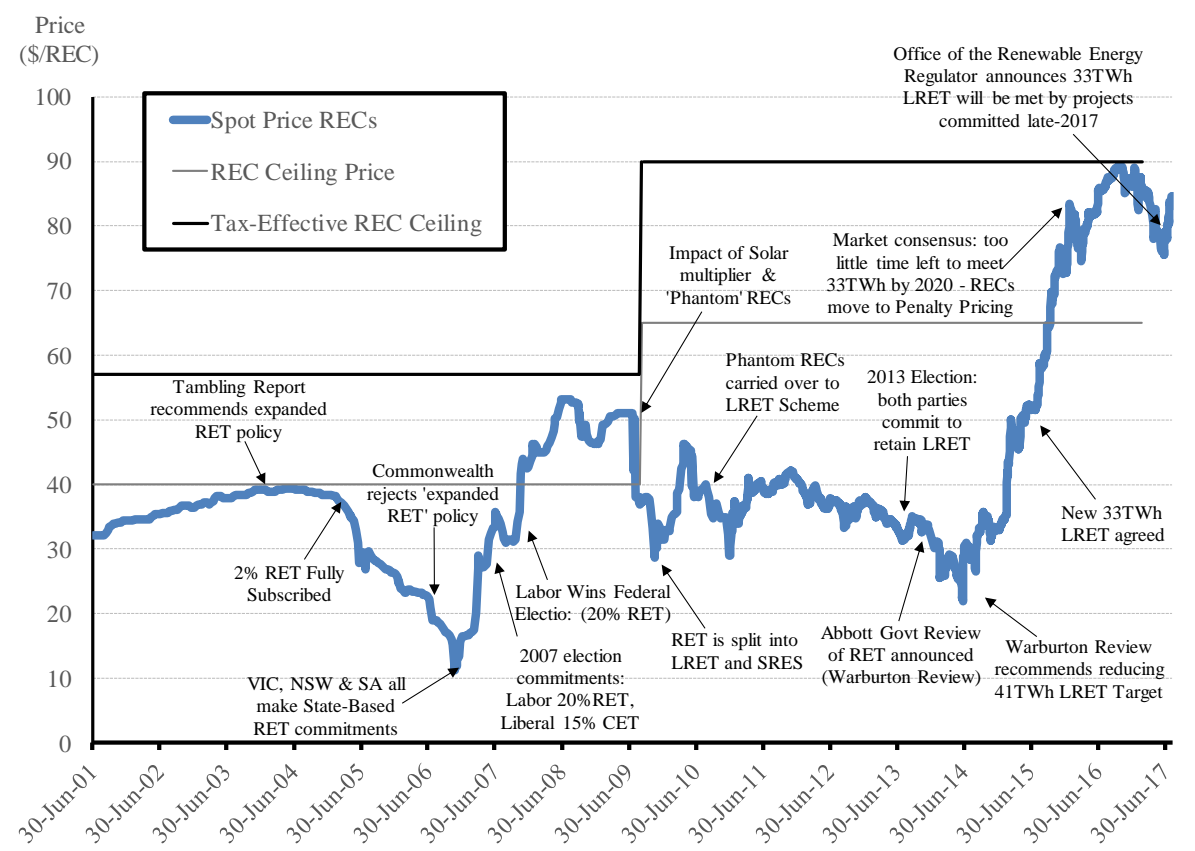

Source: Nelson et al. (2013), BNEF.

\subsection{Carbon Pricing}

As with the RET, ETS policy development also commenced from 1997 (Jones, 2010). A Cap and Trade ETS design emerged in the early 2000s after following a conventional policymaking cycle orchestrated by the then Australian Greenhouse Office (AGO, 1999a, 1999b; Nelson et al. 2010). Evidently however, Cabinet Ministers involved in sponsoring the ETS policy had misjudged the then Prime Minister's appetite for internalising $\mathrm{CO}_{2}$ emissions due to perceived adverse effects on Australia's low cost energy; consequently the policy was discarded before legislative drafting commenced (Simshauser \& Tiernan, 2017). With Australia's international greenhouse gas commitment known, and no matching policy framework, sub-national State Governments filled the policy vacuum in Australia - just as occurred in the US and Canada (Schelly, 2014; Jones, 2014). ${ }^{14}$ In 2003, NSW introduced the world's first $\mathrm{CO}_{2}$ ETS $^{15}$ and as noted in Section 2.1 Queensland implemented its 15\% Clean Energy Target with gas and renewable set-asides (MacGill et al 2006; Jones 2009; Nelson et al 2010). Both schemes were highly successful in that they met their objectives faster and at lower cost than any market forecast at the time (Daly \& Edis, 2010). Given the success of the NSW and Queensland schemes, inaction by the Commonwealth, underpinned by the fact that all sub-national governments had migrated to social democratic leaders, in 2006 Australia's state governments agreed to a "State-based National ETS" (NETT, 2006; Jones, 2014). As Nelson et al. (2010) explain, with every state committed the so-called NETT policy was credible and taken seriously by industry.

The 2007 commonwealth election produced two election commitments in response; the incumbent conservative government was forced to adopt an ETS policy and the opposition social

\footnotetext{
${ }^{14}$ Jones (2014) highlights there is no national scheme in Canada, but Ontario (and Quebec) operate sub-national schemes. Schelly (2014) explains there is no national climate policy in the US per se and consequently States have taken a leadership role; more than half of the US state have a Renewable Portfolio Standard although ironically, no two schemes are alike. Peters and Hertel (2017) note that in August 2015 the US Environmental Protection Agency announced the Clean Power Plan to reduce CO2 emissions by 32\% below 2005 levels by 2030 - but they also note Business As Usual is likely to achieve this target.

${ }^{15}$ As Daly \& Edis (2010) note, the US initiated the first Cap and Trade schemes in the market for $\mathrm{SO}_{\mathrm{x}}$. The NSW 'Baseline and Credit' mechanism was organised with electricity retailers being the liable party and subjected to a gradually declining ' $\mathrm{CO}_{2}$ per capita' target. Although a NSW scheme, it was open beyond the borders of NSW and extended to any facility connected to the National Electricity Market. More than $130 \mathrm{CO}_{2}$-emitting facilities qualified and abatement of $73 \mathrm{mt}$ was achieved prior to scheme closure in 2010. See Nelson et al. (2010) for further details.
} 
democratic party, informed by the work of state counterparts, also adopted an ETS policy (Jones, 2010; Nelson et al 2010). Thus after 10-years of uncertainty a central tenet of climate change policy was finally bi-partisan (Garnaut, 2014).

Following the 2007 national election, the new social democratic government progressed legislation for an ETS (Buckman \& Diesendorf, 2010; Jones, 2010). NSW and Queensland closed down their respective state-base schemes to remove the risk of policy duplication (Nelson, 2015). However, a change in conservative party leadership in late-2009 grounded in an anti-ETS narrative meant the political environment surrounding an ETS became so toxic that the social democratic government pulled the ETS from their legislative agenda and announced it would be delayed until at least 2013 (Nelson, 2010; Jones, 2014).

A minority social democratic government emerged from the 2010 national election and revived the ETS policy with legislation passed in 2011 (Garnaut, 2014). The scheme commenced from 1 July 2012 with a $\$ \$ 23 / \mathrm{t}$ carbon price, fixed for three years before transitioning to a conventional cap and trade ETS scheme (Wild et al 2015). Despite minimal fiscal effects due to windfall tax recycling (Freebairn, 2014) the timing of the $\$ 23 / \mathrm{t}$ fixed price made the ETS scheme politically vulnerable because simultaneously, EU permits had crashed from $€ 30 / \mathrm{t}$ a few years earlier to just A $\$ 8.60 / t$. The ETS thus became central to the 2013 national election. The incoming conservative government dismantled and discarded the ETS policy for a third time, albeit following two years of operational experience.

The new conservative government replaced the ETS with a Direct Action Plan, a taxpayer funded reverse auction scheme designed to centrally purchase $\mathrm{CO}_{2}$ abatement (Apergis \& Lau, 2015) Nong \& Siriwardana (2017) and Freebairn (2014) explain the benefits and limitations of the policy but above all its fiscal durability was questionable when in 2015 Australia signed a new (and bipartisan) international agreement to reduce emissions by $26-28 \%$ below 2005 levels by 2030 at the Paris Conference of the Parties. The Commonwealth Government subsequently committed to a climate change policy review to be completed during 2017 with the 2030 emissions target in mind.

In the period leading up to the commonwealth's 2017 climate change policy review, state governments, generators, energy retailers, industry groups and energy consumer groups progressively formed a unified position around an Emissions Intensity Scheme (EIS). The "uniform baseline \& credit" ETS policy was becoming increasingly important because coal plant began to exit and gas-fired plant was being withdrawn (Forrest \& MacGill, 2013; Bell et al 2015; Apergis \& Lau 2015; Bell et al. 2017). But within hours of announcing the climate change policy inquiry and the prospect of an EIS as the policy mechanism, a conservative party backbench revolt led to direct intervention by the Prime Minister, and the EIS policy option was discarded before the review had even started (Simshauser \& Tiernan, 2017).

Following the collapse of the SA power system the Commonwealth government initiated a review of the NEM to be led by the Chief Scientist. The Finkel Review, noting the EIS had been discarded, proceeded by reaching into the garbage can and recovering a 2007 policy option - a Clean Energy Target. Yet within weeks of being announced, commonwealth government support for the "CET" policy alternative began to unwind and by October 2017 had been discarded.

At the time of writing, a policy vacuum will exist in both strands of climate policy, Carbon Pricing \& Renewable Energy Targets after 2020. If nothing else, Australia's climate change policy garbage can is full, with many practical experiments along the way. 


\section{Nature of the problem: plant exit and plant entry}

Australia and the USA are both characterised by vast coal, gas and renewable resources, acute differences in State and Federal positions on climate change policy and as Byrnes et al (2013) and Schelly (2014) note respectively, a lack of a united energy and climate change policy structure at the national level. But in the US, climate change policies of subnational governments and their Renewable Portfolio Standards in particular have been durable, whereas in Australia national climate change policies are best described as discontinuous as Section 2 explained. The effects of this becomes evident from the entry statistics in Tables 1-5.

Table 1 outlines the existing US generation fleet and catalogues plant entry commitments by decade (from 1930- through to 2010-). Coal, gas and non-hyrdo renewable plant are separately identified. Note that Total Plant incorporates these technologies along with other plants such as hydroelectric, nuclear, oil-fired and so on. The total fleet is 1,183,280MW with an average age of 29 years, including 855 coal plants totalling $286,721 \mathrm{MW}$ with a fleet average age of 39 years.

Table 1: US Generation Fleet in Service (1930-2017)

\begin{tabular}{|c|c|c|c|c|c|c|c|c|}
\hline \multirow{2}{*}{$\begin{array}{c}\text { Year of } \\
\text { Operating } \\
\text { Duty }\end{array}$} & \multicolumn{2}{|c|}{ Coal Plant } & \multicolumn{2}{|c|}{ Gas Plant } & \multicolumn{2}{|c|}{ Non-Hydro Renewables } & \multicolumn{2}{|c|}{ Total Plant } \\
\hline & $\begin{array}{c}\text { Number of } \\
\text { Plant }\end{array}$ & $\begin{array}{c}\text { Installed } \\
\text { Capacity } \\
(\mathrm{MW})\end{array}$ & $\begin{array}{l}\text { Number of } \\
\text { Plant }\end{array}$ & $\begin{array}{c}\text { Installed } \\
\text { Capacity } \\
(\mathrm{MW})\end{array}$ & $\begin{array}{c}\text { Number of } \\
\text { Plant }\end{array}$ & $\begin{array}{c}\text { Installed } \\
\text { Capacity } \\
(\mathrm{MW})\end{array}$ & $\begin{array}{c}\text { Number of } \\
\text { Plant }\end{array}$ & $\begin{array}{c}\text { Installed } \\
\text { Capacity (MW) }\end{array}$ \\
\hline $1930-1939$ & 4 & 10,579 & 5 & 29 & 3 & 19 & 1658 & 41,922 \\
\hline $1940-1949$ & 19 & 14,483 & 36 & 774 & 14 & 159 & 478 & 42,911 \\
\hline 1950-1959 & 147 & 35,130 & 201 & 15,131 & 49 & 671 & 1172 & 77,404 \\
\hline 1960-1969 & 172 & 48,078 & 299 & 33,526 & 50 & 1,311 & 1551 & 120,629 \\
\hline 1970-1979 & 230 & 65,707 & 573 & 59,916 & 33 & 930 & 1794 & 203,037 \\
\hline 1980-1989 & 165 & 47,035 & 375 & 15,144 & 186 & 3,863 & 2101 & 123,117 \\
\hline 1990-1999 & 67 & 21,087 & 731 & 53,009 & 125 & 3,327 & 2241 & 104,916 \\
\hline 2000-2009 & 25 & 34,750 & 2056 & 270,109 & 704 & 33,948 & 5043 & 335,882 \\
\hline $2010-$ & 26 & 9,873 & 471 & 63,919 & 3001 & 73,004 & 4884 & 133,462 \\
\hline Total & 855 & 286,721 & 8328 & 511,558 & 4843 & 117,231 & 20922 & $1,183,280$ \\
\hline Average Age & & 39 Yrs & & 21 Yrs & & 8 Yrs & & 29 Yrs \\
\hline
\end{tabular}

Table 2 isolates Coal Retirements (i.e. exit) from 2005-2017, and contrasts this with Gas Plant Entry and Renewable Entry. Note that 629 coal plants have exited totalling 61,624MW, representing $18 \%$ of the US coal-fleet. At exit, the average age of plant was 52 years. Coal plant exit follows sharp declines in gas prices, the introduction of mercury standards, resource constraints, $30 \%$ capital (tax-credit) subsidies for solar and wind, and stable Renewable Portfolio Standards in more than half of the US states (Schelly, 2014; Peters \& Hertel, 2017).

From an entry perspective, 889 gas generators totalling 117,958MW have replaced coal plant exits and importantly, 87,416MW of this is base/semi-base Combined Cycle Gas Turbine (CCGT) plant. Furthermore, 3542 renewable projects totalling 102,447MW have been commissioned.

Table 2: US Coal Plant Exit vs Gas \& Renewable Entry

\begin{tabular}{|c|c|c|c|c|c|c|c|}
\hline \multirow{2}{*}{\begin{tabular}{|l|} 
Year of \\
Exit/Entry
\end{tabular}} & \multicolumn{2}{|c|}{ Coal Retirements } & \multicolumn{3}{|c|}{ Gas Plant Entry } & \multicolumn{2}{|c|}{ Renewable Entry } \\
\hline & $\begin{array}{c}\text { Number of } \\
\text { Plant }\end{array}$ & $\begin{array}{c}\text { Installed } \\
\text { Capacity } \\
\text { (MW) }\end{array}$ & $\begin{array}{c}\text { Number of } \\
\text { Plant }\end{array}$ & $\begin{array}{l}\text { Installed } \\
\text { Capacity } \\
(\mathrm{MW})\end{array}$ & $\begin{array}{c}\text { CCGT } \\
\text { Component } \\
\text { (MW) }\end{array}$ & $\begin{array}{c}\text { Number of } \\
\text { Plant }\end{array}$ & $\begin{array}{c}\text { Installed } \\
\text { Capacity } \\
\text { (MW) }\end{array}$ \\
\hline $2005-2012$ & 245 & 11,257 & 648 & 81,775 & 72,925 & 1500 & 57,449 \\
\hline 2013- & 384 & 50,367 & 241 & 36,183 & 14,490 & 2042 & 44,998 \\
\hline Total & 629 & 61,624 & 889 & 117,958 & 87,416 & 3542 & 102,447 \\
\hline Average Age & & $52 \mathrm{Yrs}$ & & & & & \\
\hline \multicolumn{2}{|c|}{ Coal Fleet Closure $(\%)$} & $18 \%$ & & & & & \\
\hline
\end{tabular}


Table 3 provides an equivalent overview of plant in service in Australia. Australia has $24,436 \mathrm{MW}$ of coal plant with an average age of 30 years, and total installed capacity of $62,578 \mathrm{MW}$ with a fleet average age of 26 years.

Table 3: Australian Generation Fleet in Service (1930-2017)

\begin{tabular}{|c|c|c|c|c|c|c|c|c|}
\hline & \multicolumn{2}{|c|}{ Coal Plant } & \multicolumn{2}{|c|}{ Gas Plant } & \multicolumn{2}{|c|}{ Non-Hydro Renewables } & \multicolumn{2}{|c|}{ Total Plant } \\
\hline & $\begin{array}{c}\text { Number of } \\
\text { Plant }\end{array}$ & $\begin{array}{c}\text { Installed } \\
\text { Capacity } \\
(\mathrm{MW})\end{array}$ & $\begin{array}{c}\text { Number of } \\
\text { Plant }\end{array}$ & $\begin{array}{c}\text { Installed } \\
\text { Capacity } \\
(\mathrm{MW})\end{array}$ & $\begin{array}{c}\text { Number of } \\
\text { Plant }\end{array}$ & $\begin{array}{c}\text { Installed } \\
\text { Capacity } \\
(\mathrm{MW})\end{array}$ & $\begin{array}{c}\text { Number of } \\
\text { Plant }\end{array}$ & $\begin{array}{c}\text { Installed } \\
\text { Capacity (MW) }\end{array}$ \\
\hline 1930-1939 & 0 & 0 & 0 & 0 & 1 & 28 & 4 & 105 \\
\hline 1940-1949 & 0 & 0 & 1 & 60 & 1 & 29 & 3 & 117 \\
\hline 1950-1959 & 0 & 0 & 0 & 0 & 6 & 139 & 15 & 1,302 \\
\hline 1960-1969 & 0 & 0 & 1 & 480 & 9 & 157 & 25 & 5,530 \\
\hline 1970-1979 & 3 & 5,025 & 4 & 1,377 & 21 & 256 & 35 & 9,928 \\
\hline 1980-1989 & 4 & 11,780 & 7 & 1,687 & 6 & 86 & 51 & 15,539 \\
\hline 1990-1999 & 3 & 4,226 & 26 & 2,806 & 58 & 404 & 59 & 7,666 \\
\hline $2000-2009$ & 6 & 3,197 & 38 & 9,212 & 125 & 2,139 & 178 & 16,147 \\
\hline $2010-$ & 1 & 208 & 14 & 3,075 & 79 & 3,271 & 142 & 6,244 \\
\hline Total & 17 & 24,436 & 91 & 18,697 & 306 & 6,511 & 512 & 62,578 \\
\hline Average Age & & $30 \mathrm{Yrs}$ & & 17 Yrs & & 12 Yrs & & 26 Yrs \\
\hline
\end{tabular}

Table 4 outlines coal exit and non-coal entry statistics. Australian coal plant exit results are strikingly similar to the US on a proportional basis. Where a stark difference exists is Gas Plant Entry and Renewables Entry.

Table 4: Australian Coal Plant Exit vs Gas \& Renewable Entry

\begin{tabular}{|c|c|c|c|c|c|c|c|}
\hline \multirow{2}{*}{\begin{tabular}{|l|} 
Year of \\
Exit/Entry
\end{tabular}} & \multicolumn{2}{|c|}{ Coal Retirements } & \multicolumn{3}{|c|}{ Gas Plant Entry } & \multicolumn{2}{|c|}{ Renewables Entry } \\
\hline & $\begin{array}{c}\text { Number of } \\
\text { Plant }\end{array}$ & $\begin{array}{c}\text { Installed } \\
\text { Capacity } \\
(\mathrm{MW})\end{array}$ & $\begin{array}{c}\text { Number of } \\
\text { Plant }\end{array}$ & $\begin{array}{c}\text { Installed } \\
\text { Capacity } \\
(\mathrm{MW})\end{array}$ & $\begin{array}{c}\text { CCGT } \\
\text { Component } \\
(\mathrm{MW})^{*}\end{array}$ & $\begin{array}{c}\text { Number of } \\
\text { Plant }\end{array}$ & $\begin{array}{c}\text { Installed } \\
\text { Capacity } \\
(\mathrm{MW})\end{array}$ \\
\hline $2005-2012$ & 2 & 740 & 31 & 8,674 & 2,546 & 112 & 2,640 \\
\hline $2013-$ & 9 & 4,656 & 4 & 218 & 52 & 49 & 2,422 \\
\hline Total & 11 & 5,396 & 35 & 8,892 & 2,598 & 161 & 5,062 \\
\hline Average Age & & 42 Yrs & & & \multicolumn{2}{|c|}{ *Swanbank E mothballed in 2015} & \\
\hline Coal Fleet Clo & are $(\%)$ & $18 \%$ & & & & & \\
\hline
\end{tabular}

Table 5 provides comparative statistics between the two countries. The first point to note is Coal Fleet Exit is $18 \%$ in both countries. The major difference lies in plant entry; Australian semi-base CCGT Plant Entry is one-third of the US result (1.4x vs $0.5 x)$ and Renewable Plant Entry is half the US result (1.7x vs 0.9x). Both CCGT plant and Renewables have an energy-production bias (as distinct from Open Cycle Gas Turbines, which have a peak capacity bias). US statistics do not represent an "optimal target" per se, but comparative analysis provides clues as to why energy prices in the NEM have risen as coal plant has exited, and why US prices remain low and stable in spite of an equivalent episode of coal plant exit.

Table 5: US and Australian entry/exit ratios

\begin{tabular}{|l|c|c|c|c|c}
\hline & $\begin{array}{c}\text { Coal Fleet } \\
\text { Exit }\end{array}$ & $\begin{array}{c}\text { Average } \\
\text { Exit Age }\end{array}$ & $\begin{array}{c}\text { Gas Plant Entry } \\
\text { Ratio }\end{array}$ & $\begin{array}{c}\text { CCGT } \\
\text { Component }\end{array}$ & $\begin{array}{c}\text { Renewables } \\
\text { Plant Entry Ratio }\end{array}$ \\
\hline USA & $18 \%$ & 52 Yrs & $1.9 x$ Coal Exit & $1.4 x$ Coal Exit & $1.7 x$ Coal Exit \\
\hline Australia & $18 \%$ & 42 Yrs & $1.6 x$ Coal Exit & $0.5 x$ Coal Exit & $0.9 . x$ Coal Exit \\
\hline
\end{tabular}

Source: US EIA, esaa, BNEF.

The difference in Renewables entry is explained by policy discontinuity; in Australia the commonwealth government has reviewed the RET on six separate occasions and fundamentally altered the policy three times whereas in the US, state-based Renewable Portfolio Standards have 
been comparatively stable. The differential in gas-fired plant entry is explained in Sections 4 and 5 .

\section{PF model and the generalised cost of plant}

In order to analyse entry dynamics and relevant policy settings, it is helpful to identify generalised long run marginal costs of NEM entrants. The PF Model, a dynamic multi-period post-tax discounted cash flow model, has been designed specifically for this purpose. It solves for multiple generating technologies, business combinations and financing structures and simultaneously determines convergent price, debt-sizing and post-tax equity returns, $K_{e}$. Firststage outputs are similar to levelised cost estimates but with a level of detail well beyond conventional Levelised Cost of Electricity Model estimates because corporate and project financing constraints and taxation variables are co-optimised. Key data inputs are presented in Tables 6-7 for five new entrant technologies over three time-horizons with two financing structures. Note they assume entry at scale:

Table 6: Technology Assumptions 2007-2017

\begin{tabular}{|c|c|c|c|c|c|c|c|c|c|c|c|}
\hline Technology & Capex & $\begin{array}{l}\text { Installed } \\
\text { Capacity }\end{array}$ & $\begin{array}{r}\text { Generating } \\
\text { Units }\end{array}$ & $\begin{array}{r}\text { Unit Heat } \\
\text { Rate }\end{array}$ & $\begin{array}{r}\text { Unit Fuel } \\
\text { Cost }\end{array}$ & $\begin{array}{r}\text { Capacity } \\
\text { Factor }\end{array}$ & $\begin{array}{r}\text { Fixed O\&M } \\
\text { Cost }\end{array}$ & $\begin{array}{r}\text { Variable } \\
\text { O\&M }\end{array}$ & $\begin{array}{l}\text { Capital } \\
\text { Works }\end{array}$ & $\begin{array}{r}\text { Auxillary } \\
\text { Load }\end{array}$ & $\begin{array}{r}\text { Carbon } \\
\text { Intensity }\end{array}$ \\
\hline & $(\$ / \mathrm{kW})$ & (MW) & (MW) & $(\mathrm{kJ} / \mathrm{kWh})$ & $(\$ / G J)$ & $(\%)$ & (\$/MW/a) & $(\$ / \mathrm{MWh})$ & $(\%)$ & $(\%)$ & $(\mathrm{t} / \mathrm{MWh})$ \\
\hline \multicolumn{12}{|l|}{2007 Inputs } \\
\hline Black Coal & 1,500 & 1,000 & 2 & 9,500 & 1.00 & $90 \%$ & 48,000 & 1.00 & $0.25 \%$ & $7.00 \%$ & 0.87 \\
\hline Brown Coal & 2,250 & 1,000 & 2 & 12,150 & 0.40 & $90 \%$ & 55,000 & 1.30 & $0.25 \%$ & $8.00 \%$ & 1.10 \\
\hline CCGT & 1,200 & 380 & 1 & 7,000 & 3.25 & $85 \%$ & 10,000 & 3.00 & $0.05 \%$ & $2.00 \%$ & 0.36 \\
\hline Wind & 2,100 & 200 & 100 & - & - & $37 \%$ & 40,000 & 1.00 & $0.05 \%$ & $2.00 \%$ & - \\
\hline Solar PV & 4,000 & 20 & - & - & - & $24 \%$ & 62,000 & - & $0.05 \%$ & $0.50 \%$ & - \\
\hline \multicolumn{12}{|l|}{2012 Inputs } \\
\hline Black Coal & 2,250 & 1,000 & 2 & 9,000 & 1.25 & $90 \%$ & 49,250 & 2.00 & $0.25 \%$ & $7.10 \%$ & 0.82 \\
\hline Brown Coal & 3,000 & 1,000 & 2 & 11,613 & 0.40 & $90 \%$ & 60,250 & 4.00 & $0.25 \%$ & $9.60 \%$ & 1.05 \\
\hline CCGT & 1,250 & 380 & 1 & 6,965 & 5.50 & $85 \%$ & 10,000 & 7.00 & $0.05 \%$ & $3.00 \%$ & 0.36 \\
\hline Wind & 2,500 & 450 & 180 & - & - & $39 \%$ & 45,000 & 1.00 & $0.05 \%$ & $2.00 \%$ & - \\
\hline Solar PV & 3,500 & 100 & - & - & - & $28 \%$ & 59,435 & & $0.05 \%$ & $0.50 \%$ & - \\
\hline \multicolumn{12}{|l|}{2017 Inputs } \\
\hline Black Coal & 3,050 & 1,000 & 2 & 8,450 & 1.54 & $90 \%$ & 50,500 & 4.00 & $0.25 \%$ & $7.10 \%$ & 0.77 \\
\hline Brown Coal & 4,000 & 1,000 & 2 & 11,150 & 0.40 & $90 \%$ & 65,500 & 5.00 & $0.25 \%$ & $9.60 \%$ & 1.01 \\
\hline CCGT & 1,500 & 380 & 1 & 6,930 & 8.00 & $85 \%$ & 10,000 & 7.00 & $0.05 \%$ & $3.00 \%$ & 0.36 \\
\hline Wind & 1,787 & 450 & 118 & - & - & $41 \%$ & 50,000 & 1.00 & $0.05 \%$ & $2.00 \%$ & - \\
\hline Solar PV & 1,500 & 100 & - & - & - & $30 \%$ & 56,870 & - & $0.05 \%$ & $1.00 \%$ & - \\
\hline
\end{tabular}


Table 7: Corporate Finance Assumptions

\begin{tabular}{|c|c|c|c|c|c|c|c|c|c|}
\hline Wind \& Solar & & 2007 & 2012 & 2017 & Coal \& Gas & & 2007 & 2012 & 2017 \\
\hline Debt Sizing Constraints & & & & & Debt Sizing Constraints & & & & \\
\hline - DSCR & (times) & 1.35 & 1.35 & 1.35 & - FFO/I & (times) & 5 & 5 & 5 \\
\hline - LLCR & (times) & 1.35 & 1.35 & 1.35 & - FFO/D & (times) & 3 & 3 & 3 \\
\hline - Gearing Limit & $(\%)$ & 85.0 & 85.0 & 65.0 & - Gearing Limit & $(\%)$ & 35.0 & 35.0 & 35.0 \\
\hline - Default & (times) & 1.10 & 1.10 & 1.10 & & & & & \\
\hline \multicolumn{2}{|c|}{ Project Finance Facilities - Tenor } & & & & \multicolumn{2}{|c|}{ Corporate 'BBB' Bond Issue } & & & \\
\hline - Tranche 1 (Bullet) & (Yrs) & 5 & 5 & 5 & - Tranche 1 (Bullet) & (Yrs) & 5 & 5 & 5 \\
\hline - Tranche 1 Refi & (Yrs) & $13-20$ & $13-20$ & $13-20$ & - Tranche 1 Refi & (Yrs) & $13-20$ & $13-20$ & $13-20$ \\
\hline - Tranche 2 (Amort.) & (Yrs) & 12 & 12 & 7 & - Tranche 2 (Amort.) & (Yrs) & 12 & 12 & 7 \\
\hline - Tranche 2 Refi & (Yrs) & $6-13$ & $6-13$ & $6-13$ & - Tranche 2 Refi & (Yrs) & $6-13$ & $6-13$ & $6-13$ \\
\hline - Notional amortisation & (Yrs) & $18-25$ & $18-25$ & $18-25$ & - Notional amortis ation & (Yrs) & $18-25$ & $18-25$ & $18-25$ \\
\hline \multicolumn{2}{|c|}{ Project Finance Facilities - Pricing } & & & & BBB' Bond Pricing & & & & \\
\hline - Tranche 1 Swap & $(\%)$ & 6.14 & 3.69 & 2.45 & - Tranche 1 & $(\%)$ & 6.69 & 6.26 & 3.74 \\
\hline - Tranche 1 Margin & (bps) & 120 & 250 & 200 & - Tranche 1 Margin & (bps) & 54 & 257 & 129 \\
\hline - Tranche 2 Swap & $(\%)$ & 6.10 & 3.98 & 2.66 & - Tranche 2 & $(\%)$ & 6.78 & 6.55 & 4.15 \\
\hline - Tranche 2 Margin & (bps) & 140 & 275 & 220 & - Tranche 2 Margin & (bps) & 69 & 257 & 149 \\
\hline - Tranche 1 & $(\%)$ & 7.34 & 6.19 & 4.45 & - Tranche 1 & $(\%)$ & 6.69 & 6.26 & 3.74 \\
\hline - Tranche 2 & $(\%)$ & 7.50 & 6.73 & 4.86 & - Tranche 2 & $(\%)$ & 6.78 & 6.55 & 4.15 \\
\hline - Tranche $1 \& 2$ Refi & $(\%)$ & 7.50 & 6.73 & 4.86 & - Tranche $1 \& 2$ Refi & $(\%)$ & 6.78 & 6.55 & 4.15 \\
\hline - Post Tax Equity & $(\%)$ & 15.0 & 12.0 & 8.5 & - Post Tax Equity & $(\%)$ & 12.0 & 12.0 & 12.0 \\
\hline
\end{tabular}

\subsection{PF Model}

Costs increase annually by a forecast general inflation rate (CPI). Prices escalate at a discount to CPI. Inflation rates for revenue streams $\pi_{j}^{R}$ and cost streams $\pi_{j}^{C}$ in period (year) $j$ are calculated as follows:

$\pi_{j}^{R}=\left[1+\left(\frac{C P I \times \alpha_{R}}{100}\right)\right]^{j}$, and $\pi_{j}^{C}=\left[1+\left(\frac{C P I \times \alpha_{C}}{100}\right)\right]^{j}$

The discounted value for $\alpha_{R}$ reflects single factor learning rates that characterise generating technologies.

Energy output $\rho_{j}^{i}$ from each plant $(i)$ in each period $(j)$ is a key variable in driving revenue streams, unit fuel costs and variable Operations \& Maintenance costs. Energy output is calculated by reference to installed capacity $k^{i}$, capacity utilisation rate $C F_{j}^{i}$ for each period $j$. Plant auxillary losses $A u x^{i}$ arising from on-site electrical loads are deducted.

$\rho_{j}^{i}=C F_{j}^{i} \cdot k^{i} \cdot\left(1-A u x^{i}\right)$

A convergent electricity price for the $i^{\text {th }}$ plant $\left(p^{i \varepsilon}\right)$ is calculated in year one and escalated per eq. (1). ${ }^{16}$ Thus revenue for the $i^{\text {th }}$ plant in each period $j$ is defined as follows:

$R_{j}^{i}=\left(\rho_{j}^{i} \cdot p^{i \varepsilon} \cdot \pi_{j}^{R}\right)$

In order to define marginal running costs, the thermal efficiency for each generation technology $\zeta^{i}$ needs to be defined. The constant term ' $3600{ }^{\prime 17}$ is divided by $\zeta^{i}$ to convert the efficiency

\footnotetext{
${ }^{16}$ Note that thermal plant also earns ancillary services revenue, which in the model equates to about $0.3 \%$ of electricity sales. This has been the historic average although as VRE increases, this can be expected to change dramatically.

${ }^{17}$ The derivation of the constant term 3600 is: 1 Watt $=1$ Joule per second and hence 1 Watt Hour $=3600$ Joules.
} 
result from $\%$ to $\mathrm{kJ} / \mathrm{kWh}$. This is then multiplied by raw fuel commodity cost $f^{i}$. Variable Operations \& Maintenance $\operatorname{costs} v^{i}$, where relevant, are added which produces a pre-carbon short run marginal cost. Under conditions of externality pricing $C P_{j}$, the $\mathrm{CO}_{2}$ intensity of output needs to be defined. Plant carbon intensity $g^{i}$ is derived by multiplying the plant heat rate by combustion emissions $\dot{g}^{i}$ and fugitive $\mathrm{CO}_{2}$ emissions $\hat{g}^{i}$. Marginal running costs in the $j^{\text {th }}$ period is then calculated by the product of short run marginal production costs by generation output $\rho_{j}^{i}$ and escalated at the rate of $\pi_{j}^{C}$.

$\vartheta_{j}^{i}=\left\{\left[\left(\frac{\left(3600 / \zeta^{i}\right)}{1000} \cdot f^{i}+v^{i}\right)+\left(g^{i} \cdot C P_{j}\right)\right] \cdot \rho_{j}^{i} \cdot \pi_{j}^{C} \mid g^{i}=\left(\dot{g}^{i}+\hat{g}^{i}\right) \cdot \frac{\left(3600 / \zeta^{i}\right)}{1000}\right\}$

Fixed Operations \& Maintenance costs $F O M_{j}^{i}$ of the plant are measured in $\$ / \mathrm{MW} /$ year of installed capacity $F C^{i}$ and are multiplied by plant capacity $k^{i}$ and escalated.

$F O M_{j}^{i}=F C^{i} \cdot k^{i} \cdot \pi_{j}^{C}$

Earnings Before Interest Tax Depreciation and Amortisation (EBITDA) in the $j^{\text {th }}$ period can therefore be defined as follows:

$\operatorname{EBITDA} A_{j}^{i}=\left(R_{j}^{i}-\vartheta_{j}^{i}-F O M_{j}^{i}\right)$

Capital Costs $\left(X_{0}^{i}\right)$ for each plant $i$ are Overnight Capital Costs and incurred in year $0 .{ }^{18}$ Ongoing capital spending for each period $j$ is determined as the inflated annual assumed capital works program.

$x_{j}^{i}=c_{j}^{i} \cdot \pi_{j}^{C}$

Plant capital costs $X_{0}^{i}$ give rise to tax depreciation $\left(d_{j}^{i}\right)$ such that if the current period was greater than the plant life under taxation law $(L)$, then the value is 0 . In addition, $x_{j}^{i}$ also gives rise to tax depreciation such that:

$d_{j}^{i}=\left(\frac{x_{0}^{i}}{L}\right)+\left(\frac{x_{j}^{i}}{L+1-j}\right)$

From here, taxation payable $\left(\tau_{j}^{i}\right)$ at the corporate taxation rate $\left(\tau_{c}\right)$ is applied to EBITD $A_{j}^{i}$ less Interest on Loans $\left(I_{j}^{i}\right)$ later defined in (16), less $d_{j}^{i}$. To the extent $\left(\tau_{j}^{i}\right)$ results in non-positive outcome, tax losses $\left(L_{j}^{i}\right)$ are carried forward and offset against future periods.

$\operatorname{Max}\left(\tau_{j}^{i}, 0\right)=\left(\operatorname{EBITD} A_{j}^{i}-I_{j}^{i}-d_{j}^{i}-L_{j-1}^{i}\right) \cdot \tau_{c}$

The debt financing model computes interest and principal repayments on different debt facilities depending on the type, structure and tenor of tranches. There are two types of debt facilities - (a) corporate facilities (i.e. balance-sheet financings) and (2) project financings. Debt structures include semi-permanent amortising facilities and bullet facilities.

\footnotetext{
${ }^{18}$ The model is capable of dealing with multi-period construction programs such that $X_{j}^{i}=-\sum_{k=1}^{N} C_{k}$. $\left(1+K_{e}\right)^{-k}$. However, for the present exercise, all plant capital costs are 'Overnight Capital Costs' (i.e. as if the plant were purchased at the completion of construction) and therefore include an allowance for capitalised interest during construction.
} 
Corporate Finance involve 5- and 7-year bond issues with an implied 'BBB' credit rating. Project Finance include a 5-7 year bullet facility requiring interest-only payments after which it is refinanced with consecutive amortising facilities and fully amortised over an $18-25$ year period depending on the technoligy. The second facility commences with a tenor of 7-12 years as an amortising facility set within a semi-permanent structure with a nominal repayment term of 18-25 years. The decision tree for the two tranches of debt was the same, so for the Debt Tranche where $T=1$ or 2 , the calculation is as follows:

if $j\left\{\begin{array}{l}>1, D T_{j}^{i}=D T_{j-1}^{i}-P_{j-1}^{i} \\ =1, D T_{1}^{i}=D_{0}^{i} . S\end{array}\right.$

$D_{0}^{i}$ refers to the total amount of debt used in the project. The split $(S)$ of the debt between each facility refers to the manner in which debt is apportioned to each tranche. In the model, 35\% of debt is assigned to Tranche 1 and the remainder to Tranche 2 . Principal $P_{j-1}^{i}$ refers to the amount of principal repayment for tranche $T$ in period $j$ and is calculated as an annuity:

$P_{j}^{i}=\left(\frac{D T_{j}^{i}}{\left[\frac{1-\left(1+\left(R_{T}^{Z}+C_{T}^{Z}\right)\right)^{-n}}{R_{T}^{Z}+C_{T}^{Z}}\right]} \mid z\left\{\begin{array}{l}=V I \\ =P F\end{array}\right)\right.$

In (15), $R_{T}$ is the relevant interest rate swap (5yr, $7 \mathrm{yr}$ or $12 \mathrm{yr}$ ) and $C_{T}$ is the credit spread or margin relevant to the issued Debt Tranche. The relevant interest payment in the $j^{\text {th }}$ period $\left(I_{j}^{i}\right)$ is calculated as the product of the (fixed) interest rate on the loan by the amount of loan outstanding:

$I_{j}^{i}=D T_{j}^{i} \times\left(R_{T}^{Z}+C_{T}^{Z}\right)$

Total Debt outstanding $D_{j}^{i}$, total Interest $I_{j}^{i}$ and total Principle $P_{j}^{i}$ for the $i^{t h}$ plant is calculated as the sum of the above components for the two debt tranches in time $j$. For clarity, Loan Drawings are equal to $D_{0}^{i}$ in year 1 as part of the initial financing and are otherwise 0 .

One of the key calculations is the initial derivation of $D_{0}^{i}$ (eq.10). This is determined by the product of the gearing level and the Overnight Capital Cost $\left(X_{0}^{i}\right)$. Gearing levels are formed by applying a cash flow constraint based on credit metrics applied by project banks and capital markets. The variable $\gamma$ in our PF Model relates specifically to the legal structure of the business and the credible capital structure achievable. The two relevant legal structures are Vertically Integrated (VI) merchant utilities (issuing 'BBB' rated bonds) and Independent Power Producers using Project Finance (PF).

if $\gamma\left\{\begin{array}{l}=V I, \operatorname{Min}\left(\frac{F F O_{j}^{i}}{I_{j}^{i}}\right) \geq \delta_{j}^{V I \wedge} \operatorname{Min}\left(\frac{D_{j}^{i}}{E B I T D A_{j}^{i}}\right) \geq \omega_{j}^{V I} \forall j \mid F F O_{j}^{i}=\left(E B I T D A_{j}^{i}-x_{j}^{i}\right) \\ =\operatorname{PF}, \operatorname{Min}\left(D S C R_{j}^{i}, L L C R_{j}^{i}\right) \geq \delta_{j}^{P F}, \forall j \mid D S C R_{j}=\frac{\left(E B I T D A_{j}^{i}-x_{j}^{i}-\tau_{j}^{i}\right)}{P_{j}^{i}+I_{j}^{i}}, L L C R_{j}=\frac{\sum_{j=1}^{N}\left[\left(E B I T D A_{j}^{i}-x_{j}^{i}-\tau_{j}^{i}\right) \cdot\left(1+K_{d}\right)^{-j}\right]}{D_{j}^{i}}\end{array}\right.$

The variables $\delta_{j}^{V I}$ and $\omega_{j}^{V I}$ are exogenously determined by credit rating agencies and are outlined in Table 3. Values for $\delta_{j}^{P F}$ are exogenously determined by project banks and depend on technology (i.e. thermal vs. renewable) and the extent of energy market exposure, that is whether a Power Purchase Agreement exists or not. For clarity, $F F O_{j}^{i}$ is 'Funds From Operations' while $D S C R_{j}^{i}$ and $L L C R_{j}^{i}$ are the Debt Service Cover Ratio and Loan Life Cover Ratios. 
At this point, all of the necessary conditions exist to produce estimates of the long run marginal cost of power generation technologies. The relevant equation to solve for the price $\left(p^{i \varepsilon}\right)$ given expected equity returns $\left(K_{e}\right)$ whilst simultaneously meeting the binding constraints of $\delta_{j}^{V I}$ and $\omega_{j}^{V I}$ or $\delta_{j}^{P F}$ given the relevant business combination is as follows:

$-X_{0}^{i}+\sum_{j=1}^{N}\left[E B I T D A_{j}^{i}-I_{j}^{i}-P_{j}^{i}-\tau_{j}^{i}\right] \cdot\left(1+K_{e}\right)^{-(j)}-\sum_{j=1}^{N} x_{j}^{i} \cdot\left(1+K_{e}\right)^{-(j)}-D_{0}^{i}$

The primary objective is to expand every term which contains $p^{i \varepsilon}$. Expansion of the EBITDA and Tax terms is as follows:

$-X_{0}^{i}+\sum_{j=1}^{N}\left[\left(p^{i \varepsilon} \cdot \rho_{j}^{i} \cdot \pi_{j}^{R}\right)-\vartheta_{j}^{i}-F O M_{j}^{i}-I_{j}^{i}-P_{j}^{i}-\left(\left(p^{i \varepsilon} \cdot \rho_{j}^{i} \cdot \pi_{j}^{R}\right)-\vartheta_{j}^{i}-F O M_{j}^{i}-I_{j}^{i}-d_{j}^{i}-L_{j-1}^{i}\right) \cdot \tau_{c}\right] .(1+$ $\left.K_{e}\right)^{-(j)}-\sum_{j=1}^{N} x_{j}^{i}\left(1+K_{e}\right)^{-(j)}-D_{0}^{i}$

The terms are then rearranged such that only the $p^{i \varepsilon}$ term is on the left hand side of the equation:

Let $I R R \equiv K_{e}$

$\sum_{j=1}^{N}\left(1-\tau_{c}\right) \cdot p^{i \varepsilon} \cdot \rho_{j}^{i} \cdot \pi_{j}^{R} \cdot\left(1+K_{e}\right)^{-(j)}=X_{0}^{i}-\sum_{j=1}^{N}\left[-\left(1-\tau_{c}\right) \cdot \vartheta_{j}^{i}-\left(1-\tau_{c}\right) \cdot F O M_{j}^{i}-\left(1-\tau_{c}\right) \cdot\left(I_{j}^{i}\right)-P_{j}^{i}+\right.$

$\left.\left.\tau_{c} \cdot d_{j}^{i}+\tau_{c} L_{j-1}^{i}\right) \cdot\left(1+K_{e}\right)^{-(j)}\right]+\sum_{j=1}^{N} x_{j}^{i} \cdot\left(1+K_{e}\right)^{-(j)}+D_{0}^{i}$

The model then solves for $P^{\varepsilon}$ such that:

$$
\begin{aligned}
& p^{i \varepsilon}=\frac{X_{0}^{i}}{\sum_{j=1}^{N}\left(1-\tau_{c}\right) \cdot P^{\varepsilon} \cdot \rho_{j}^{i} \cdot \pi_{j}^{R} \cdot\left(1+K_{e}\right)^{-(j)}}+\frac{\left.\sum_{j=1}^{N}\left(\left(1-\tau_{c}\right) \cdot \vartheta_{j}^{i}+\left(1-\tau_{c}\right) \cdot F O M_{j}^{i}+\left(1-\tau_{c}\right) \cdot\left(I_{j}^{i}\right)+P_{j}^{i}-\tau_{c} \cdot d_{j}^{i}-\tau_{c} L_{j-1}^{i}\right) \cdot\left(1+K_{e}\right)^{-(j)}\right)}{\sum_{j=1}^{N}\left(1-\tau_{c}\right) \cdot p^{i \varepsilon} \cdot \rho_{j}^{i} \cdot \pi_{j}^{R} \cdot\left(1+K_{e}\right)^{-(j)}}+ \\
& \frac{\sum_{j=1}^{N} x_{j}^{i} \cdot\left(1+K_{e}\right)^{-(j)}+D_{0}^{i}}{\sum_{j=1}^{N}\left(1-\tau_{c}\right) \cdot p^{i \varepsilon} \cdot \rho_{j}^{i} \cdot \pi_{j}^{R} \cdot\left(1+K_{e}\right)^{-(j)}}
\end{aligned}
$$

\subsection{Model Results: generalised entry vs incumbent plant costs}

Tables 6-7 provide sufficient data to produce generalised long run marginal cost estimates across three specific timeframes, 2007, 2012 and 2017. These dates were selected because they capture three distinct phases of generator entry costs which in turn help to explain NEM entry dynamics both historically, and in the short- to mid-term. In 2007, fuel costs and capital costs for thermal plant were at their low point. 2012 follows the Global Financial Crisis which impacted the cost of capital, and Australia's second resources boom, which profoundly impacted construction costs and therefore the installed capital cost of generating equipment. 2012 entry costs also capture early-stage fuel cost increases. The 2017 entry costs follow the sharp declines in the capital cost and cost of capital for renewable plant, ongoing capital cost increases for thermal plant and final stage gas price increases.

Figure 2 presents 2007 entry costs for the new entrant technology set including brown and black coal, CCGT, wind, solar and OCGT. These results are contrast with an incumbent (sunk and semi-depreciated) black coal plant at $\$ 37.75 / \mathrm{MWh}$, which is slightly below the cost of a new entrant coal plant at $\$ 39.79 / \mathrm{MWh}$ followed by semi-base Combined Cycle Gas Turbine (CCGT) plant at $\$ 45.99 / \mathrm{MWh}$. Entry costs for Wind, an intermittent resource, was $\$ 81$ while solar PV was well above $\$ 200 / \mathrm{MWh}$ at the time. For completeness, a peaking OCGT is included at its carrying cost of $\$ 11 / \mathrm{MWh}$ and marginal running cost of $\$ 43 / \mathrm{MWh}$, reflecting low cost gas. Notice along the $\mathrm{x}$-axis that renewable plant have $73 \%$ debt in their capital structures; these are assumed to be Project Financed whereas all other plant are conventional balance sheet or corporate financings with investment grade credit metrics (30-34\% gearing). 
Figure 2: $\quad 2007$ generalised entry costs

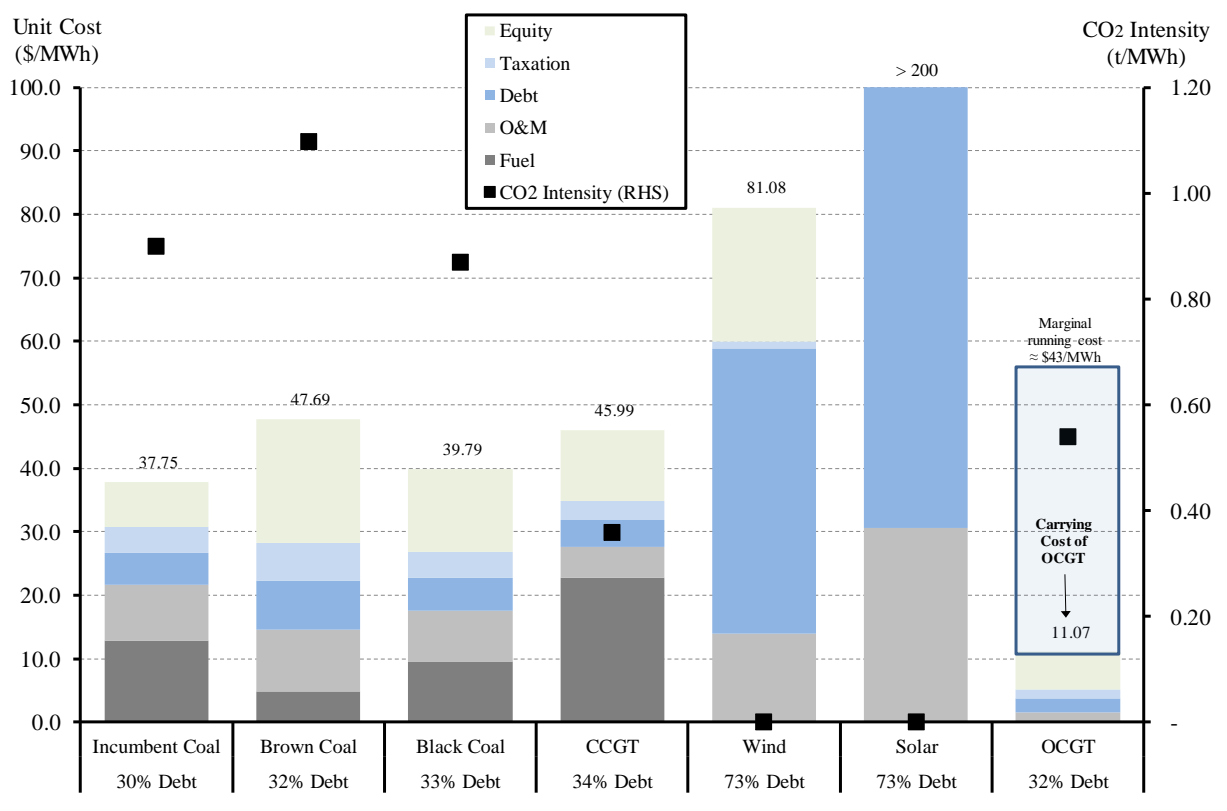

Figure 3 presents 2012 results. Notice the distinct gap emerging between semi-depreciated incumbent coal plant, new entrant coal and new gas plant - the former due to sharply rising capital costs and the latter due to rising fuel costs. However, while capital costs of all new entrants increased materially (viz. 20-50\%), for VRE plant this was largely offset by their falling cost of capital.

Figure 3: 2012 generalised entry costs

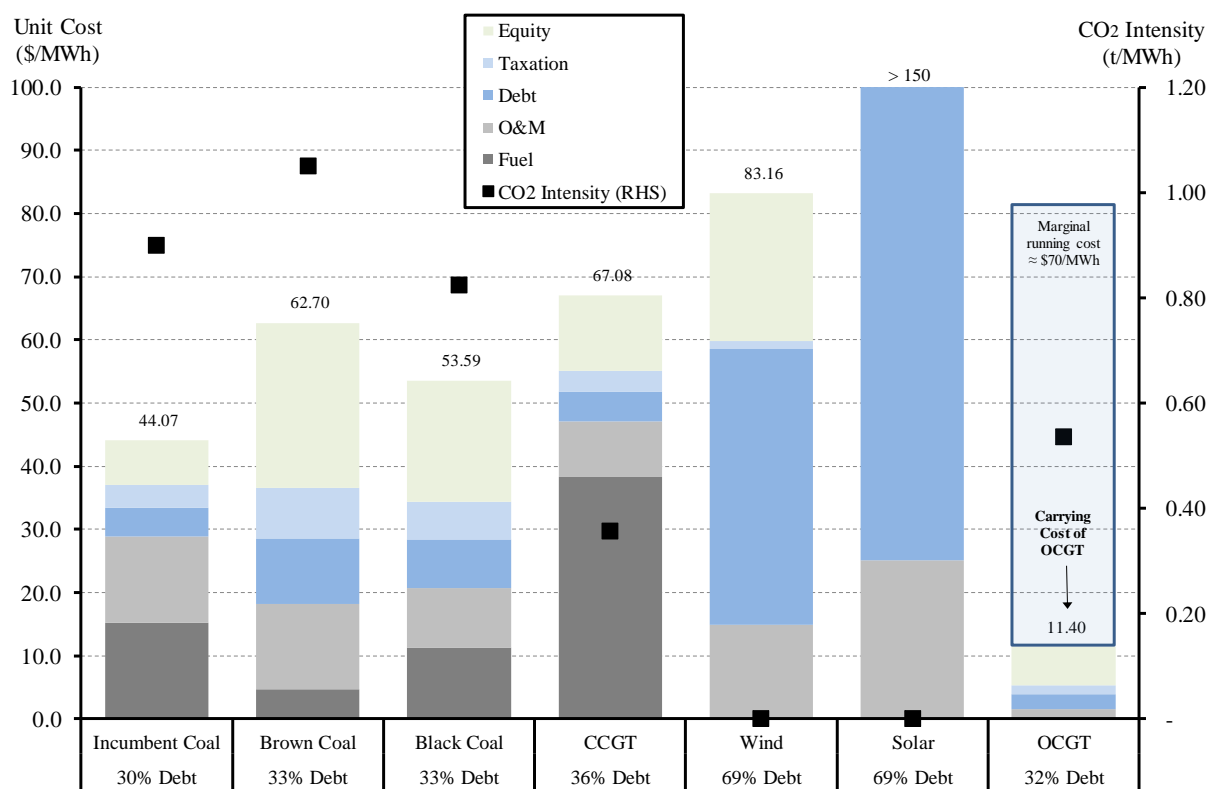

Figure 4 presents 2017 results. The gap between incumbent and new entrant coal is now material while reductions in entry costs for wind and solar are striking, reflecting international trends in renewables (see also Jaraite et al. 2017; Wiser \& Bolinger, 2017). By comparison to 2012 there are three key changes; (1) the cost of capital has fallen further, especially for project financed renewables; (2) the capital cost of thermal plant has risen by $30 \%$ whereas the capital cost of renewable plant has fallen by $30 \%$, and the relative output of wind has increased materially (from 
mid-30s to 40\%+ ACF) as Wiser \& Bolinger (2017) observe; and (3) the cost of fuels and gas in particular continues to escalate.

Figure 4: 2017 generalised entry costs

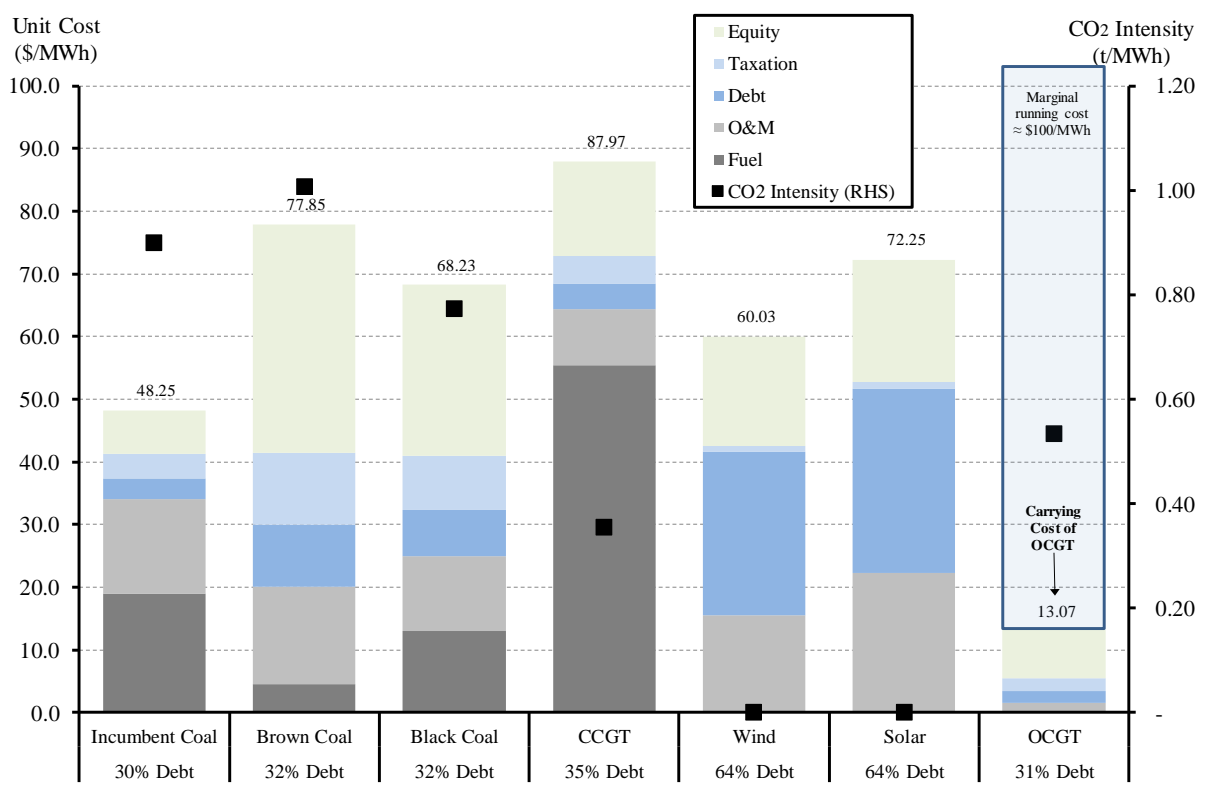

This evolution of generator entry cost dynamics has been captured in Figure 5:

Figure 5: $\quad$ Evolution of entry costs 2007-2017

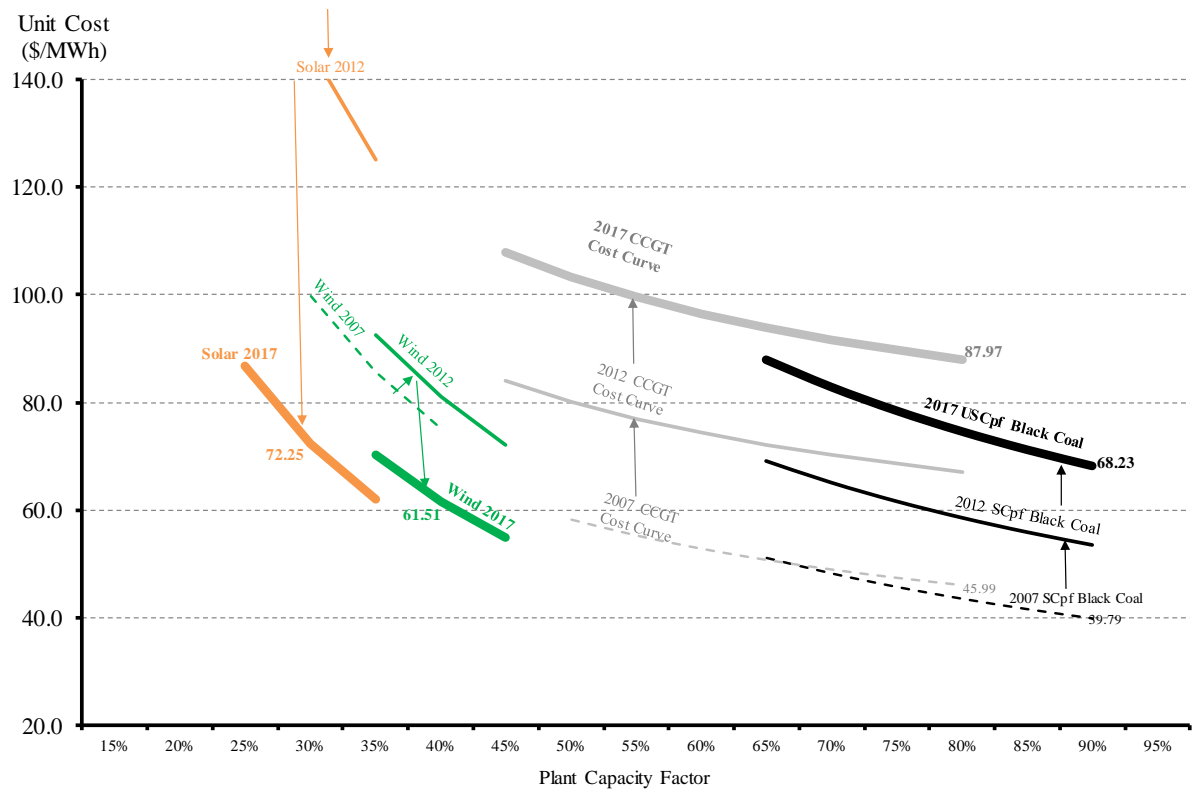

Figures 2-5 need to be interpreted carefully. First, there is no real-world observation for coal and gas-fired generation in 2017 - the numbers are engineering estimates whereas VRE results can be observed from the many projects currently under construction. Second, VRE plant are intermittent - cost estimates do not take into account the value of output and as such provide apples and oranges comparison. ${ }^{19}$ Nonetheless, in an environment that is short energy and long capacity, project financed renewables are emerging as the lowest cost entrants even in the

${ }^{19}$ Levlised Cost of Energy (LCoE) is flawed because it treats technology output as homogeneous (see MacGill, 2010; Joskow, 2011; Mills \& Wiser, 2012; Hirth, 2013; Edenhofer et al. 2013; Hirth et al. 2016; Simshauser 2017b). 
absence of a price on carbon. The caveat is that adequate flexible capacity exists - something which remains an unresolved issue for the SA region of the NEM.

\section{Gas policy, investment failure \& problem mis-specification}

The most under-analysed aspect of the NEM in my opinion is the market for natural gas in spite of the structural damage it is transmitting to the electricity market. The purpose of the Finkel Review was to provide a policy blueprint to guide "NEM adjustment" given higher levels of VRE plant and the exit of coal plant following the SA system collapse focusing event. Unfortunately problem definition by the Review was partial. As Section 3 highlighted, exit was not matched by adequate entry and most problematic by comparison to prior episodes of high spot prices was the relative failure of gas-fired plant entry in response to rising prices. This is illustrated in Figure 6 which contrasts the entry of gas-fired plant with NEM spot prices (note plant entry has been shifted forward by 2 years to account for a nominal construction lags). ${ }^{20}$ This apparent failure has been driven by an enduring episode of scarcity pricing in the gas market, and consequently the increase in the entry cost of gas-fired plant as depicted in Figures 2-5.

Figure 6: NEM gas plant entry and average spot prices

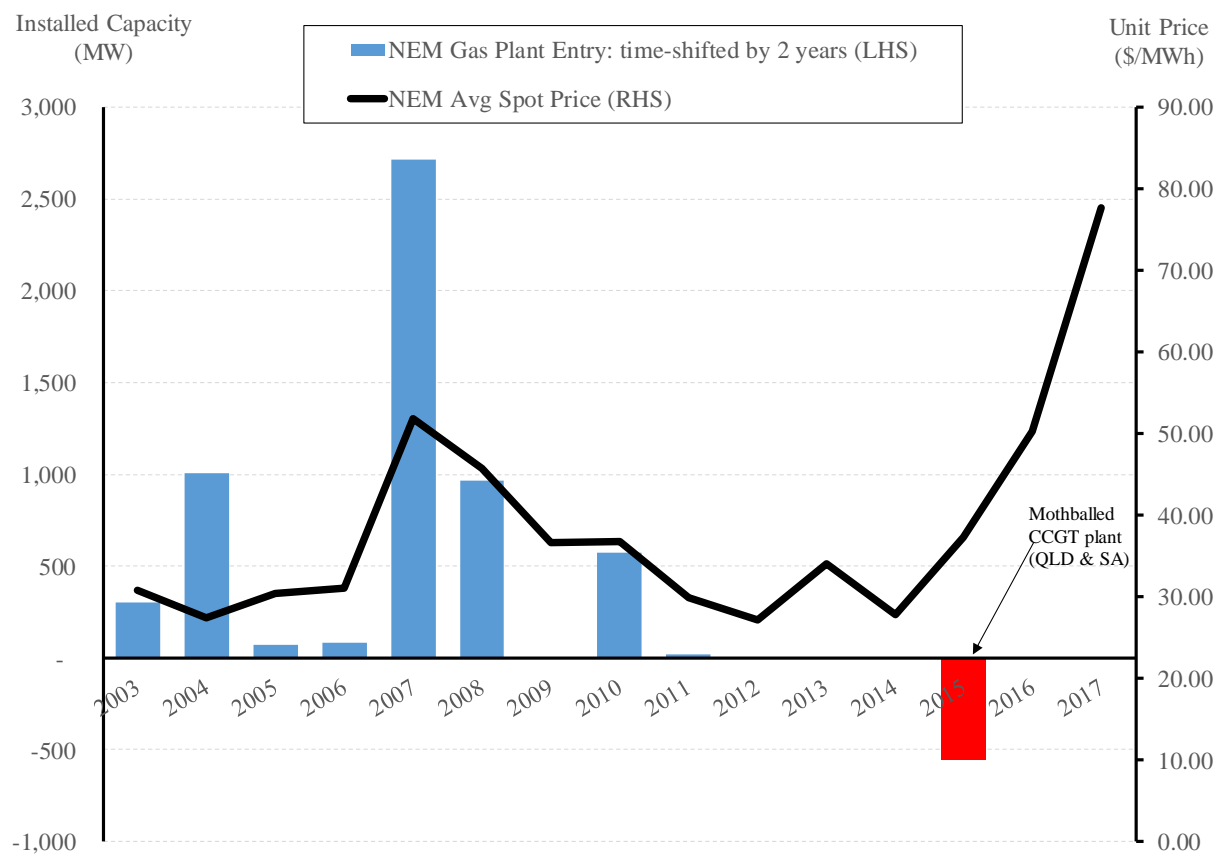

Source: esaa, AEMO.

In the 1990s the NEM's supply-side was dominated by incumbent coal-fired generation plant. New entry was also dominated by coal plant through to 2004 with four new Supercritical coalfired plant committed in Queensland. However, from 2003 to 2010 gas-fired generation increasingly became the entrant technology of choice with a noticeable increase occurring in response to elevated wholesale electricity prices in 2007-2008 as Figure 6 illustrates. But gasfired power station commitments ceased from 2010 because conditions in the gas market fundamentally changed (Molyneaux et al 2013; Wagner et al 2015). Indeed, not only did gasfired plant fail to enter, CCGT plant was being withdrawn in 2015 (see Figure 6).

${ }^{20}$ Finkel (2017, p.102) suggest 4900MW of proposed new gas-fired generation capacity has been publicly announced, based on AEMO data. However, a detailed perusal of the AEMO project data reveals (1) not a single gas-fired project has a target commissioning data, (i.e. they are all "TBA") and (2) the majority are in fact pre-2011 gas-fired projects that failed to get developed during the last price cycle. AEMO data by region is available at https://www.aemo.com.au/Electricity/National-Electricity-MarketNEM/Planning-and-forecasting/Generation-information. 
Historically, gas prices in Australia had a long-dated trading range of \$3.00-\$4.00/GJ. Large discoveries of Coal Seam Gas, well beyond what domestic markets could readily consume, led to various consortiums pursuing development of LNG export terminals. Five proponents (three credible) emerged with projects comprising 2 x $250 \mathrm{PJ} / \mathrm{a}$ capacity. Given existing domestic demand of 680PJ/a, this would have two primary effects. First, a threefold increase in gas demand via LNG exports would drive prices to the marginal cost of extraction, nominally \$5$\$ 7 / G J$, reflecting the higher underlying cost structure of marginal gas resources deployed. Second, it would link the domestic market to the export market and its associated higher prices (nominally \$6-\$9/GJ long-run netback price). Table 8 outlines details of the three LNG projects that proceeded (notionally led by Shell ${ }^{21}$, Origin Energy \& Santos) and includes commitment date, export quantities, and commissioning dates.

Table 8: Australian East Coast LNG projects

\begin{tabular}{|c|c|c|c|c|c|c|c|}
\hline $\begin{array}{c}\text { LNG } \\
\text { Project }\end{array}$ & $\begin{array}{c}\text { Domestic } \\
\text { Proponent }\end{array}$ & $\begin{array}{c}\text { Project } \\
\text { Commitment } \\
\text { Date }\end{array}$ & $\begin{array}{c}\text { Nameplate } \\
\text { Capacity } \\
(\mathrm{PJ} / \mathrm{a})\end{array}$ & $\begin{array}{c}\text { Maximum } \\
\text { Capacity } \\
(\mathrm{PJ} / \mathrm{a})\end{array}$ & $\begin{array}{c}\text { Contracted } \\
\text { Supply } \\
(\mathrm{PJ} / \mathrm{a})\end{array}$ & $\begin{array}{c}\text { Comissioning } \\
\text { Date Train 1 }\end{array}$ & $\begin{array}{c}\text { Comissioning } \\
\text { Date Train 2 }\end{array}$ \\
\hline QCLNG & Shell & 30-Oct-10 & 504 & 549 & 474 & 28-Dec-14 & 5-Jul-15 \\
\hline APLNG & Origin Energy & 04-Jul-12* & 534 & 575 & 510 & 2-Jan-16 & 6-Oct-16 \\
\hline GLNG & Santos & 13-Jan-11 & 463 & 498 & 427 & 27-Sep-15 & 25-May-16 \\
\hline TOTAL & & 1500 & 1622 & 1411 & & \\
\hline *APLNG Train 1 was committed on 28 July 2011 \\
\multicolumn{7}{|c|}{ Source: AGL Energy, EnergyEdge } \\
\hline
\end{tabular}

As Figure 7 illustrates, development of three LNG terminals resulted in final gas demand increasing from 680PJ/a to $2000 \mathrm{PJ} / \mathrm{a}$ in a period of just three years - noting that the first $680 \mathrm{PJ} / \mathrm{a}$ was developed over a 50 year period (Simshauser \& Nelson, 2015a).

Figure 7: Gas Production

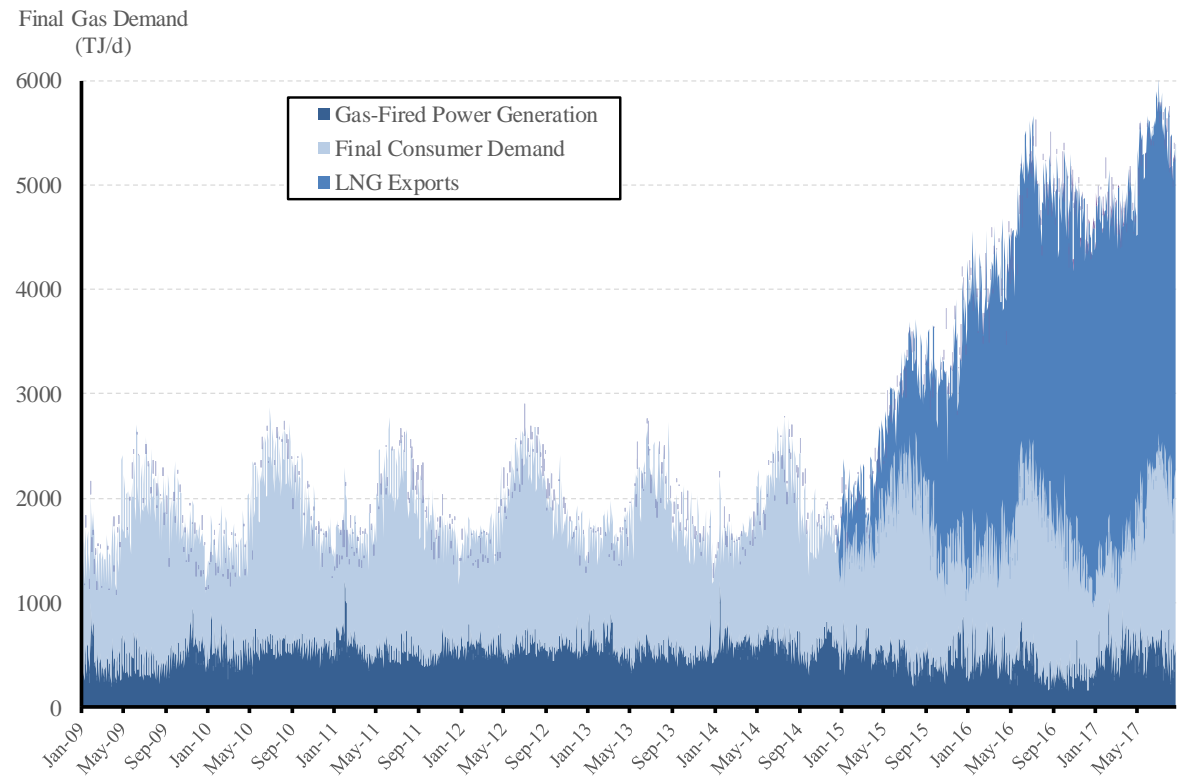

Source: EnergyEdge GMAT.

During the development phase (i.e. 2008-2012) it was widely expected that rationalisation and co-optimisation of the three competing LNG projects would occur. East coast gas reserves were adequate for two terminals $(4 \times 250 \mathrm{PJ} / \mathrm{a})$. A $5^{\text {th }} \mathrm{LNG}$ train would stretch the supply side but the

${ }^{21}$ The original project lead was BG Group following its acquisition of Queensland Gas Company. Shell announced its plans to acquire BG Group in November 2015 and was completed in February 2016. 
commitment of all six trains would represent a pure excess entry result; nonetheless all three projects were independently committed (Simshauser \& Nelson, 2015). As Garnaut (2014, p499) later observed 'benefits of gas production would be diminished by private investors' economically excessive investment in export capacity'.

Figure 8: $\quad$ LNG Plant Capacity vs Production

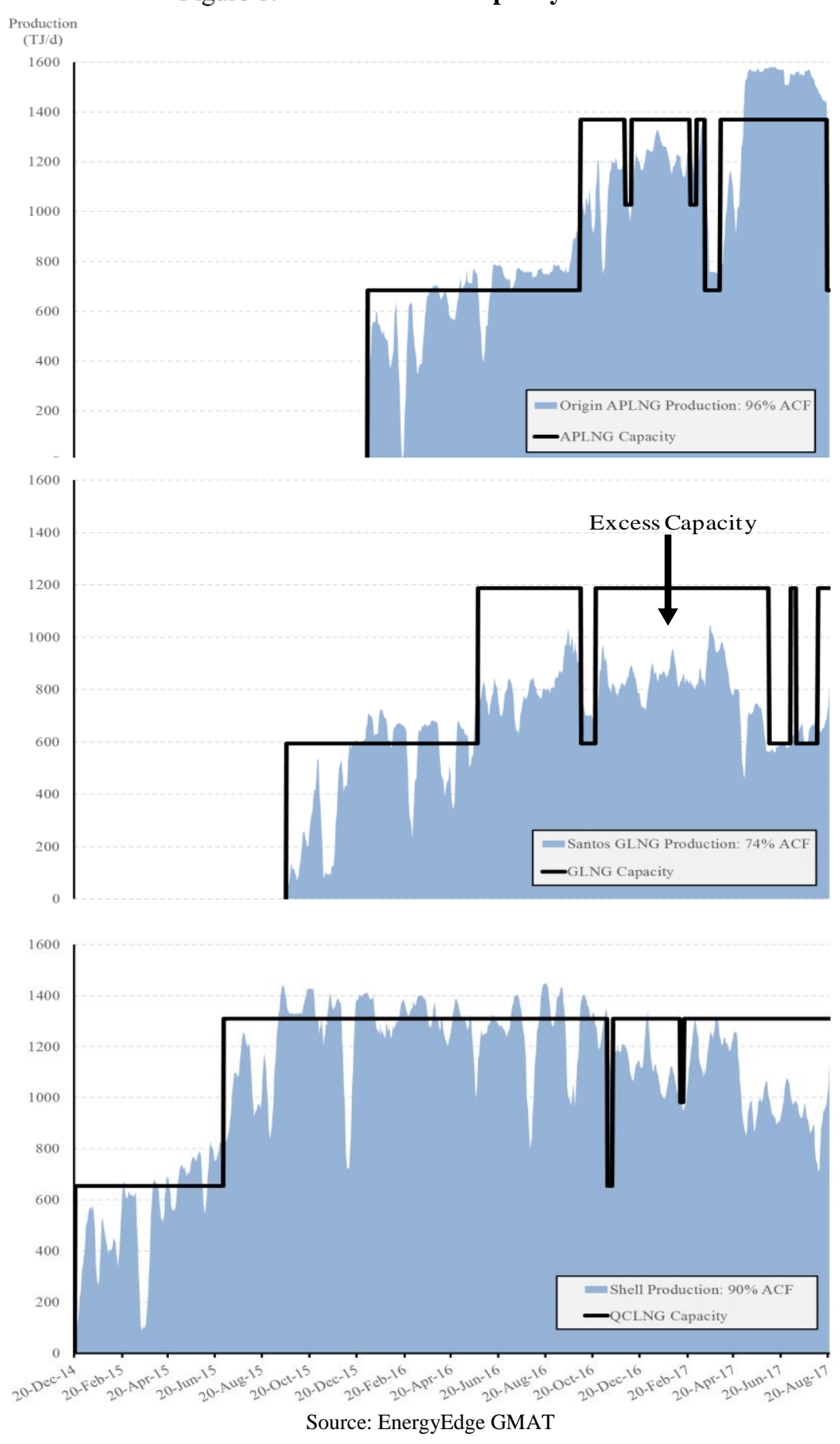

While each of the three LNG proposals would have had varying impacts on the domestic gas market at least one projects was committed yet chronically undersupplied with feedstock at Financial Close, viz. at least one of the six LNG trains was contingent on so-called " $3^{\text {rd }}$ party gas". This was significant; to operate the $6^{\text {th }}$ train, domestic market gas supply would be re- 
directed to LNG export plant. As Figure 8 illustrates, LNG plant has been running well below nameplate capacity and capital markets are well aware of these conditions.

As Garnaut (2014) explains, introducing LNG capacity meant domestic users would compete with international markets and therefore pay export parity prices. This was the accepted theory. But in reality, excess LNG capacity meant Australian domestic gas prices would rise above export parity prices because of an internal supply-demand imbalance (Garnaut, 2014; Nelson, 2015; Simshauser \& Nelson, 2015). Such an outcome is not an error of government planning or government approvals per se. Australia is not a centrally planned economy; ultimately, critical investment error by gas producers manufactured the overhang of LNG capacity as Figure 8 illustrated. That excess capacity now operates like a "Hoover" with domestic gas consumers not only needing to match export-parity market prices (i.e. long run LNG netback price), but exceed them and meet a short run 'scarcity' price (i.e. short run LNG netback price ${ }^{22}$ ). This has occurred ever since the $5^{\text {th }}$ and $6^{\text {th }}$ trains were commissioned (see Fig.9 shaded area and $\mathrm{x}$-axis annotations). Compounding matters were policy decisions to limit gas exploration, initially in NSW and later spreading to VIC and then NT. In consequence, just as it became visible that the demand-side would overshoot, the supply-side faced binding constraints.

Figure 9: $\quad$ Natural gas prices (Summer 2010-Winter 2017)

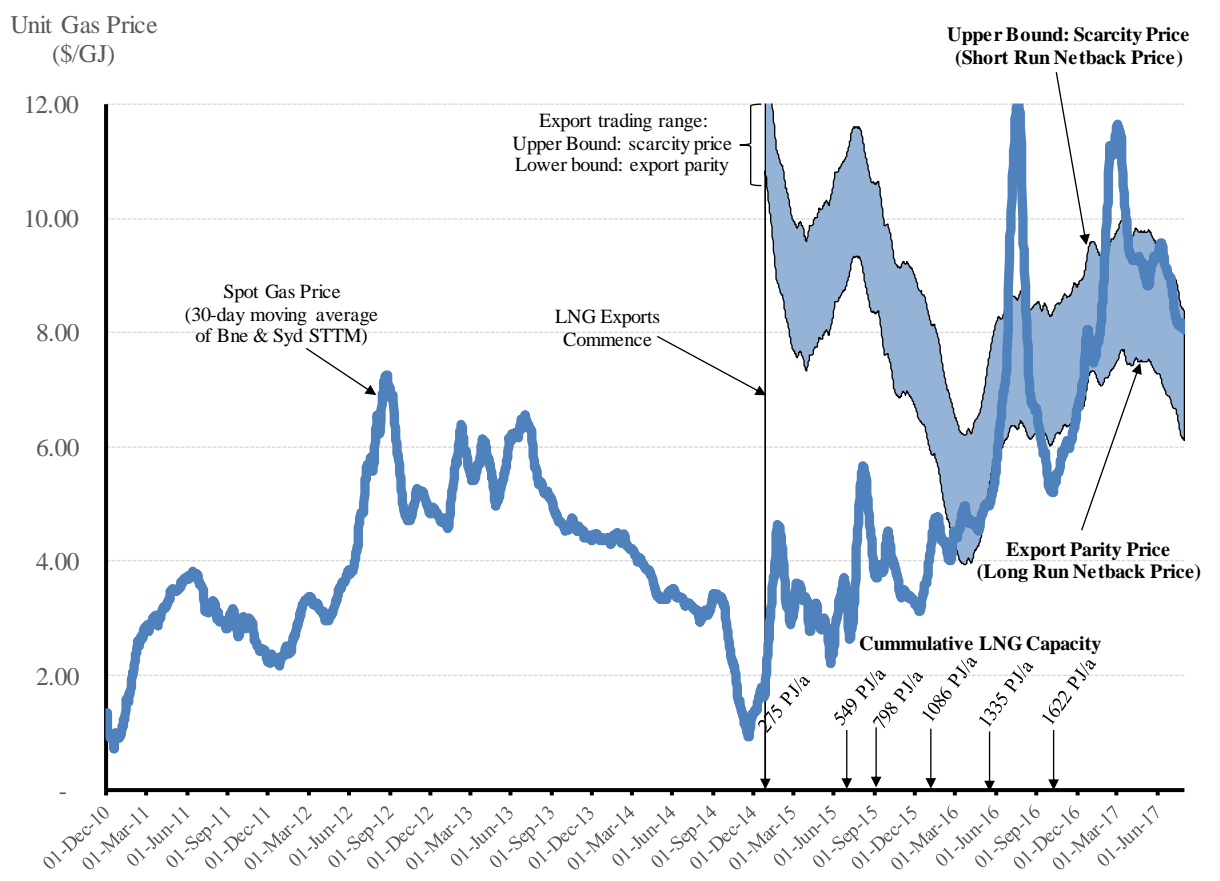

Source: Energy Edge GMAT

The result is that excess LNG capacity and the $6^{\text {th }}$ LNG train in particular has created an enduring scarcity pricing event in the gas market. Spot gas prices have risen to the top-end of the credible export-parity trading range with sporadic excursions above this (see Figure 9). And ironically, in spite of elevated domestic gas prices, the lead indicator of supply expansion (gas exploration as measured by "drill count" illustrated in Figure 10) provides little confidence that the supply-side is expanding at anywhere near the rate required to eliminate the internal imbalance. This paradox can be explained by low international oil prices, the state of incumbent oil and gas firm balance sheets following their diminished market capitalisation (see Figure 11) and an ability to hoard $2 \mathrm{P}$ reserves which are evidently rising in value based on Figure 9 data. This tends to suggest scarcity

${ }^{22}$ See Simshauser \& Nelson (2015a) and Section 4.6 in particular for the equations and a discussion on the difference between shortrun and long-run netback prices. 
pricing will persist into the future, which would meet the definition of a market failure (see also Samter et al., 2017). ${ }^{23}$ A market failure of this order is a legitimate trigger for policy intervention.

Figure 10: East Australian Drill Count

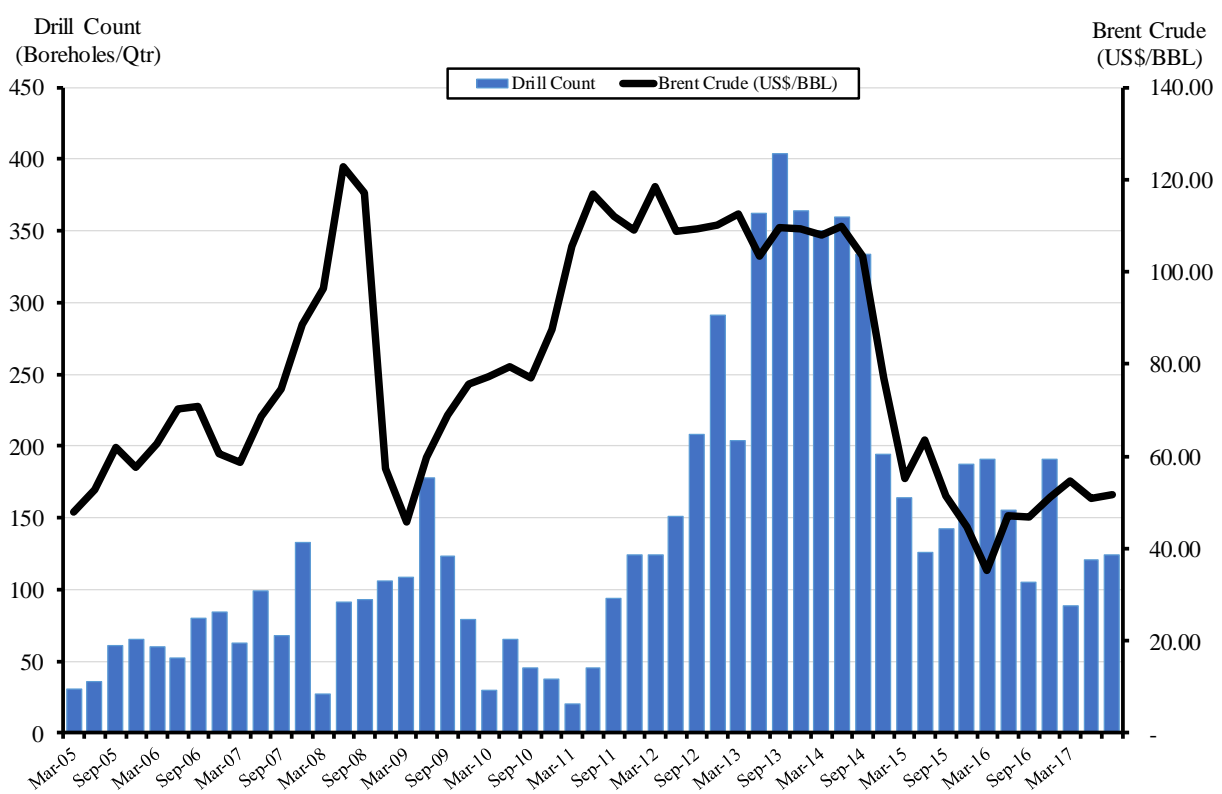

Source: EnergyEdge GMAT.

Figure 11: Market capitalisation ASX-listed east coast oil \& gas producers

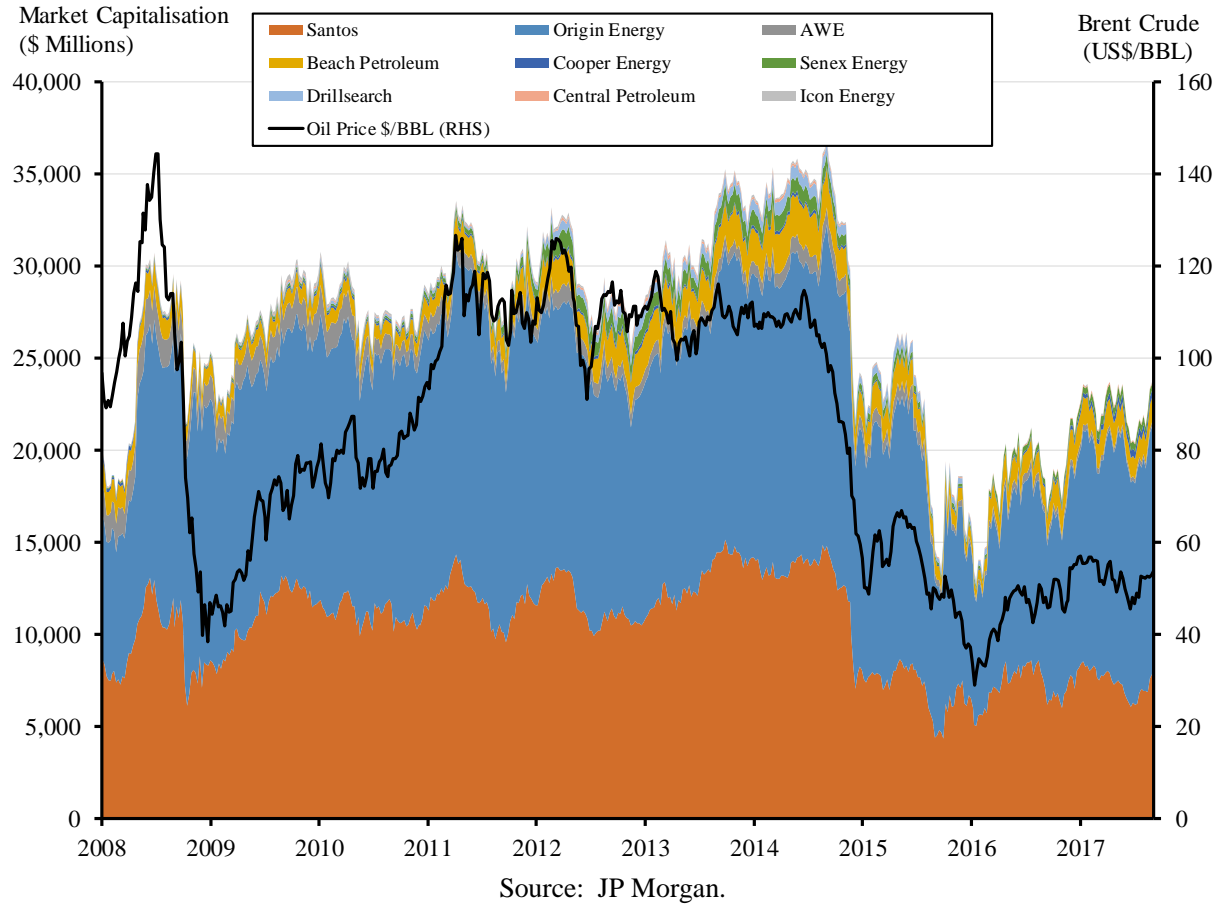

With scarcity pricing prevailing, credible long-term gas contracts (viz. 10-year tenor at fair long run cost of ca. $\$ 6-\$ 9 / G J$ at the wellhead) are unavailable. Instead the market is dominated by short-dated transactions, most recently in the $\$ 10-12+/$ GJ range. Under such conditions gas-fired

${ }^{23}$ As Samter et al. (2017, p1) argue in their research: “...What needs to stop is this nonsense argument that there is no issue with supply, it is just price. For a market to be sustained, supply needs to be available at a price that can be paid. Of course markets will balance, there is a price where that balance is just no market though ..." 
generation entry is subject to critical hold-up ${ }^{24}$ despite record spot prices in the electricity market. And as Wagner et al (2015) explain, any policy designed to force gas generation into the market (at current gas prices) would result in small emissions reductions with a very large price tag.

The gravity of LNG investment error is difficult to understate, not least because of shareholder losses but because of the state the gas market has been left in. Wholesale gas prices are operating like a wrecking-ball through gas-intensive sectors of the economy, and transmitting structural damage to the electricity sector (via gas-fired generator bid prices) which in turn is impacting all sectors of the economy. It is not inevitable that gas prices link to export prices. US gas prices were very tightly linked to oil prices until 2007 then decoupled completely as Figure 12 illustrates (Peters \& Hertel, 2017). Although an entire chapter of the Finkel Review was dedicated to the gas market there was no substantive discussion of these conditions, or recommendation on how to fix the internal market imbalance beyond being patient and increasing supply.

Figure 12: Brent Crude vs. Henry Hub 2000-2017

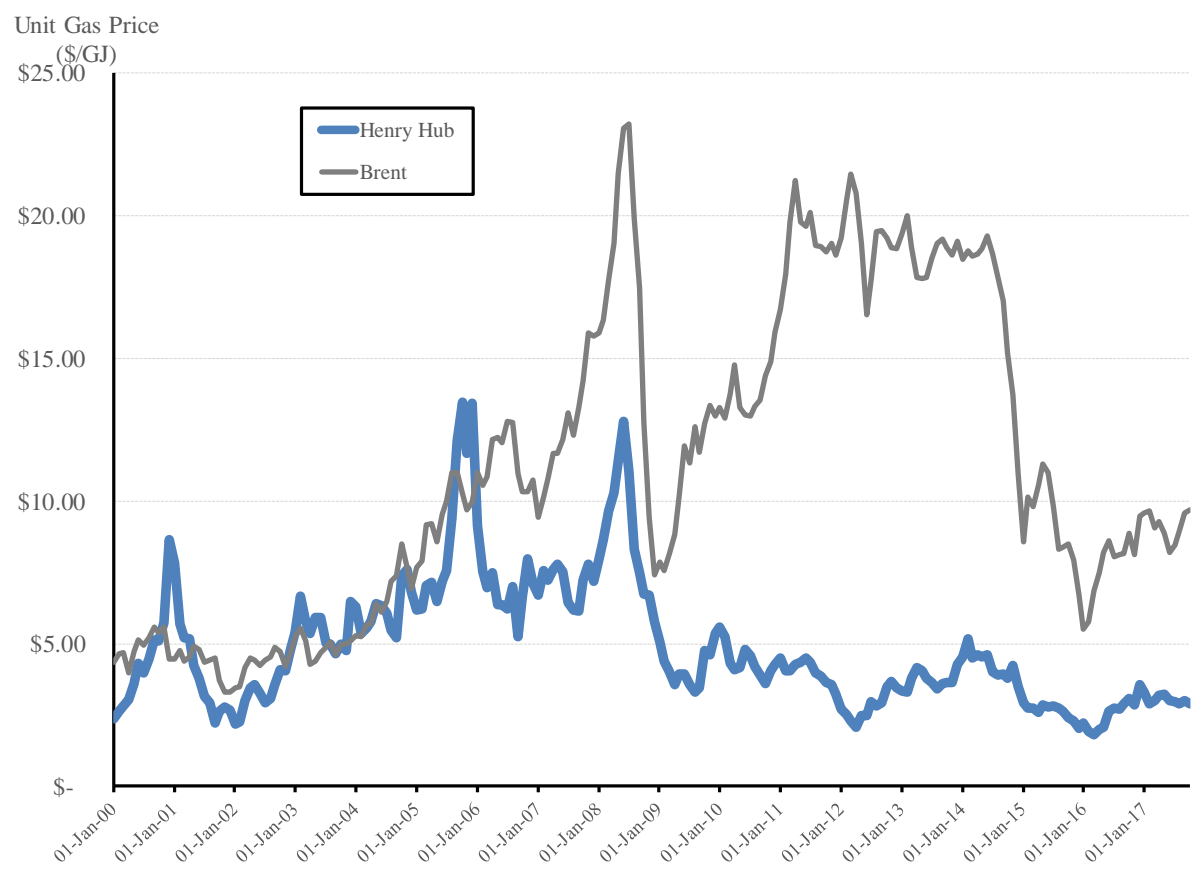

Perhaps the most sobering aspect of current gas market conditions is that current exchange rates (AUD/US0.7926) and international oil prices (US\$51.40/bbl) are favourable. A sharp run-up in oil price or depreciation of the Australian dollar would elevate gas prices. The Brent price trace in Figure 12 during Jan-11-Jun-14 should serve as a warning to policy advisers and policymakers.

In response to the gas market crisis, the Commonwealth Government introduced a contingent export control policy ${ }^{25}$ in April 2017. Under the policy, if Australia's Independent Market Operator forecasts likely gas shortages over the ensuring 12 month period, LNG exports could be curtailed by regulatory fiat - particularly where an LNG producer is unable to demonstrate they are a "net supplier" to the domestic market (viz. GLNG per Figure 8). While policymakers argue it has had an impressing effect on seasonally-adjusted spot gas prices (albeit not an evident one based on Figure 10 data), it has done nothing for the liquidity or pricing of long-dated natural gas contracts on the east coast. ${ }^{26}$ It is not credible policy because the fundamental internal supply-

\footnotetext{
${ }^{24}$ For a discussion on the relevant investment and banking conditions of generation plant entry, see Simshauser (2010).

${ }^{25}$ Known as the Australian Domestic Gas Security Mechanism or ADGSM.

${ }^{26}$ Samter et al (2017, p2) note that “... unfortunately for domestic buyers, by effectively only targeting GLNG volumes, and not price, the benchmark price for domestic gas will be set at the netback price on by far the highest price gas heading out of Curtis Island..."
} 
demand imbalance of the market has not been altered per se, it is merely a contingent policy and limited to assessing the market imbalance one year at a time. It seems that until one of the 6 LNG trains is subjected to a permanent closure event scarcity pricing will persist.

\section{Policy Implications and Concluding Remarks}

NEM conditions deteriorated sharply from mid-2016. Consistent with a requirement to progressively decarbonise the power system, $18 \%$ of the coal-fired fleet had closed but the speed of exit was not predicted by the market. Indeed only a few years earlier "barriers to exit" was the primary concern. Without a carbon price the incumbent coal-fired fleet, CCGT and VRE plant were essentially embroiled in a generalised war of attrition ${ }^{27}$.

Conversely the rate of new entry was equally unpredictable with entrants either constrained (renewables) or distorted (gas). For clarity, apart from being simply uneconomic, new Ultra Super Critical coal plant (see Figures 4-5) remains too risky for investors to contemplate due to relative $\mathrm{CO}_{2}$ emissions intensity.

Energy utilities and investors acted rationally. Given power generation equipment is among the most capital-intensive and long-lived of asset classes, investment commitment must project well beyond the current term, and political colour, of government. Two decades of climate change policy discontinuity and an increasingly dysfunctional gas market had finally taken a toll on the supply-side.

The US experienced an equivalent episode of coal-fired plant exit but this was matched by the entry of an enormous fleet of new entrant semi-base CCGT, wind and solar plant - underpinned by policy stability at the sub-national level. The good news for the NEM, if there is any, is that the rate of renewable plant entry is about to accelerate rapidly and will match US-equivalent results outlined in Section 3. Table 9 re-casts Table 5 by incorporating the NEM's 3773 MW 'bubble' of wind and solar plant currently under construction following RET policy clarity in mid-2015. This will push Australia's Renewable Plant Entry Ratio from 0.9x to 1.6x coal plant exit - almost equivalent to the $1.7 \mathrm{x}$ result in the US.

Table 9: Entry/exit ratio with Australian plant under construction

\begin{tabular}{|l|c|c|c|c|c|}
\hline & $\begin{array}{c}\text { Coal Fleet } \\
\text { Exit }\end{array}$ & $\begin{array}{c}\text { Average } \\
\text { Exit Age }\end{array}$ & $\begin{array}{c}\text { Gas Plant Entry } \\
\text { Ratio }\end{array}$ & $\begin{array}{c}\text { CCGT } \\
\text { Component }\end{array}$ & $\begin{array}{c}\text { Renewables } \\
\text { Plant Entry Ratio }\end{array}$ \\
\hline USA & $18 \%$ & 52 Yrs & $1.9 x$ Coal Exit & $1.4 x$ Coal Exit & $1.7 x$ Coal Exit \\
\hline Australia & $18 \%$ & 42 Yrs & $1.6 x$ Coal Exit & $0.5 x$ Coal Exit & 0.9.x Coal Exit \\
\hline Australia & - incorporating 3773MW of Renewables under construction & 1.6.x Coal Exit \\
\hline
\end{tabular}

The surge in renewable project commitments means the $20 \%$ RET will technically be fully subscribed by the end of 2017. Given the policy vacuum that will follow, there are fears investment in renewables may stall once again. There is no doubt that climate change policy mechanisms and renewable targets help drive investment but it is not, in my opinion, inevitable that investment will stall. Quantitative modelling in Section 4 demonstrates wind as a low cost entrant - variability aside. With electricity futures trading at $\$ 89 / \mathrm{MWh}$ and an entry cost of $\$ 60 / \mathrm{MWh}$ at scale (and perhaps $10-15 \%$ higher for smaller scale entry) new wind investments should find their way into the market and bring down wholesale prices provided the region in question maintains adequate incumbent thermal plant capacity (i.e. Queensland, NSW, Victoria). Besides which, if the Commonwealth Government recoils from a credible post-2020 climate change policy framework, utilities and investors should be confident that most if not all of the states will continue with, or initiate, their own policy initiatives - just as occurs in the US and in Canada (Schelly, 2014; Jones, 2014).

${ }^{27}$ A generalised war of attrition involves multiple participants rather than the usual two actors associated with a conventional war of attrition. See Klemperer (1999) and Simshauser (2006). 
For SA, this is not the case and there is a requirement for reliable dispatchable capacity to deal with material intermittency. This requirement would ordinarily be met by incremental CCGT and/or OCGT plant capacity. But the gas market has become dysfunctional. Unlike the electricity market which is best characterised a supply-side crisis, the gas market is a demand-side crisis. Investment error by oil and gas firms produced an LNG capacity overhang, and a market in permanent scarcity. There is no visible end to the overhang because gas supply is constrained. Consequently credible long-dated gas supply agreements, a necessary precondition for gas turbine plant financing, do not appear to be available. Commonwealth policymakers have placed temporary constraints around exports in response but this has failed to enhance liquidity or future expected prices because it is a "one year at a time" policy. I have written elsewhere that a domestic gas reservation policy would be an unhelpful development (Simshauser \& Nelson, $2014 ; 2015 a ; 2015 b)$. But this assumed that the supply-side would respond adequately to what were predictable shortages emerging in the 2017 period. For SA, this leaves battery storage as a key emerging technology.

An Emissions Intensity Scheme should remain the central focus of policy advisors and policymakers, especially at the sub-national level. In the US and in Canada, subnational governments have been successful in delivering policy clarity and continuity. In Australia, NSW and Queensland achieved similar results until they voluntarily closed their schemes to avoid policy duplication (i.e. when it appeared a credible bipartisan policy position was settled at the national level). An EIS will work "with" the NEM's organised spot market and provide a credible policy that aligns Australia's international climate change commitments with investor expectations. It will also enhance the predictability of exit decisions. Other variations on this theme could also work; above all it seems the necessary conditions are that (1) the commonwealth sets the binding emissions target, but (2) NEM states collectively decide on the mechanism to achieve that result and embed them in the state-based National Electricity Rules.

Finally, with electricity futures prices doubling, gas prices at record highs and more than 10 years of above CPI electricity price increases at the retail level, it is not surprising that affordability has resumed a central place in the current policymaking narrative. During a period of gas market failure, this heightens the mid-term importance of the incumbent coal fleet as they are the lowest cost producers - emissions aside. Consequently, reinvestment in such plant will be important in the mid-term, if only to provide much needed breathing space to policymakers. Consequently, there would be merit to any organised scheme to simultaneously focus on incumbent plant availability and $\mathrm{CO}_{2}$ emissions reductions, with a side-aim of slowing the current spate of exit decisions until entry decisions are capable of matching plant exit.

\section{References}

AGO: Australian Greenhouse Office 1999, National Emissions Trading: Establishing the Boundaries, Discussion Paper no. 1, Commonwealth of Australia, Canberra.

AGO: Australian Greenhouse Office 1999b, National Emissions Trading: Issuing the Permits, Discussion Paper no. 2, Commonwealth of Australia, Canberra.

Apergis, N. and Lau, M. 2015, "Structural breaks and electricity prices: further evidence on the role of climate policy uncertainties in the Australian electricity market", Energy Economics, 52(2015): 176-182.

Bell, W.P., Wild, P., Foster, J. and Hewson, M. 2015, "Wind speed and electricity demand correlation analysis in the Australian National Electricity Market: determining wind turbine generators' ability to meet electricity demand without energy storage", Economic Analysis \& Policy, 48(2015): 182-191.

Bell, W.P, Wild, P., Foster, J. and Hewson, M. 2017, "Revitalising the wind power induced merit-order effect to reduce wholesale and retail electricity prices in Australia", Energy Economics, 67(2017): 224-241. 
Biggs, C. 2016, "A resource-based view of opportunities to transform Australia's electricity sector", Journal of Cleaner Production, 123(2016): 203-217.

Birkland, T. 1998, "Focusing events, mobilisation and agenda setting”, Journal of Public Policy, 18(1): 5374.

Buckman, G. and Diesendorf, M. 2010, "Design limitations in Australian renewable electricity policies", Energy Policy, 38(2010): 3365-3376.

Bunn, D. and Yusupov, T. 2015, "The progressive inefficiency of replacing renewable obligation certificates with contracts-for-differences in the UK electricity market”, Energy Policy, 82(2015): 298-309.

Byrnes, L., Brown, C., Foster, J. and Wagner, L. 2013, “Australian renewable energy policy: barriers and challenges", Renewable Energy, 60(2013): 711-721.

Cludius, J., Forrest, S. and MacGill, I. 2014, "Distributional effects of the Australian Renewable Energy Target (RET) through wholesale and retail electricity price impacts”, Energy Policy, 71(2014):40-51.

Cohen, M., March, J and Olsen, J. 1972, "A garbage can model of organisational choice", Administrative Science Quarterly, 17(1): 1-25.

Daly, J. and Edis, T. 2010, "Markets to reduce pollution: cheaper than expected", Grattan Institute Report 2010-7, Melbourne.

Daly, J. and Edis, T. 2011, "Learning the hard way: Australia's policies to reduce emissions", Grattan Institute Report 2011-2, Melbourne.

Edenhofer, O., Hirth, L., Knopf, B., Pahle, M., Schlomer, S., Schmid, E. and Ueckerdt, F. 2013, "On the economics of renewable energy sources", Energy Economics, 40(2013): S12-S23.

Felder, F. 2011, "Examining electricity price suppression due to renewable resources and other grid investments", The Electricity Journal, 24(4): 34-46.

Fleischman, L., Cleetus, R., Deyette, J., Clemmer, S. and Frenkel, S. 2013, "Ripe for retirement: an economic analysis of the US coal fleet", The Electricity Journal, 26(10): 51-63.

Forrest, S. and MacGill, I. 2013, "Assessing the impact of wind generation on wholesale prices and generator dispatch in the Australian National Electricity Market”, Energy Policy, 59(2013): 120-132.

Freebairn, J. 2014, "Carbon price versus subsidies to reduce greenhouse gas emissions", Economic Papers, 33(3): 233-242.

Garnaut, R. 2014, "Resolving the energy policy dilemmas in an age of carbon constraints", Australian Economic Review, 47(4): 492-508.

Gillard, J., Swan, W. and Combet, G. 2011, Securing a Clean Energy Future: The Australian Government's Climate Change Plan. Australian Government, Canberra.

Green, R. \& Staffell, 2016, "Electricity in Europe: exiting fossil fuels?”, Oxford Review of Economic Policy, 32(2): 282-303.

Helm, D. 2014, "The return of the CEGB? Britain's central buyer model", Energy Futures Network Paper No.4, available at http://www.dieterhelm.co.uk/assets/secure/documents/The-return-of-the-CEGB.pdf (Accessed January 2017).

Hirth, L. 2013. "The market value of variable renewables: the effect of solar \& wind power variability on their relative price", Energy Economics, 38(2013): 218-236. 
Hirth, L. Ueckerdt, F. and Edenhofer, O. 2016, "Why wind is not coal: on the economics of electricity generation", The Energy Journal, 37(3): 1-27.

Howlett, M., McConnell, A. and Perl, A. 2014, "Streams and stages: reconciling Kingdon and policy process theory", European Journal of Political Research, 54(3): 419-434.

Jaraite, J., Karimu, A. and Kazukaukas, A. 2017, "Policy-induced expansion of solar and wind capacity: economic growth and employment in EU countries", The Energy Journal, 38(5): 197-222.

Jones, S. 2009, "The future of renewable energy in Australia: a test for cooperative federalism?", Australian Journal of Public Administration, 68(1): 1-20.

Jones, S. 2010, “The national Renewable Energy Target: an example of Post-Machiavellian policymaking?", Australian Journal of Public Administration, 69(2): 165-177.

Jones, S. 2014, "Flirting with climate change: a comparative policy analysis of subnational governments in Canada and Australia", Journal of Comparative Policy Analysis: Research \& Practice, 16(5): 424-440.

Jotzo, F. and Mazouz, S. 2015, "Brown coal exit: a market mechanism for regulated closure of highly emissions intensive power stations", Economic Analysis \& Policy, 48(2015): 71-81.

Joskow, P. 2011, "Comparing the costs of intermittent and dispatchable electricity generating technologies", American Economic Review, 100(3): 238-241.

Keay, M. 2016, "Electricity markets are broken - can they be fixed?", OIES Paper EL17, The Oxford Institute for Energy Studies, University of Oxford.

Kingdon, J. 1984, Agendas, Alternatives and Public Policies, Longman, New York

Kingdon, J. 1995, Agendas, Alternatives and Public Policies, $2^{\text {nd }}$ edn, Harper Collins, New York.

Kozlov, N. 2014, "Contracts for difference: risks faced by generators under the new renewables support scheme in the UK", Journal of World Energy Law and Business, 7(3): 282-286.

MacGill, I., Outhred, H. and Nolles, K. 2006, "Some design lessons from market-based greenhouse gas regulation in the restructured Australian electricity industry", Energy Policy, 34(2006): 11-25.

MacGill, I. 2010. "Electricity market design for facilitating the integration of wind energy: experience and prospects with the Australian National Electricity Market", Energy Policy, 38(2010): 3180-3191.

Mills, A. \& Wiser, R. 2012. "Changes in the economic value of variable generation at high penetration levels: a pilot case study of California", LBNL-5445E, Lawrence Berkeley National Laboratory.

Molyneaux, L., Froome, C., Wagner, L. and Foster, J. 2013, “Australian power: can renewable technologies change the dominant industry view?", Renewable Energy, 60(2013): 215-221.

Nelson, T. 2015, “Australian climate change policy - where to from here?", Economic Papers, 34(4): 257272.

Nelson, T., Kelley, S., Orton, F. and Simshauser, P. 2010, "Delayed carbon policy certainty and electricity prices in Australia", Economic Papers, 29(4): 446-465.

Nelson, T., Simshauser, P. \& Kelley, S. 2011, “Australian residential solar Feed-in Tariffs: industry stimulus or regressive form of taxation”, Economic Analysis \& Policy, 41(2): 113-129.

Nelson, T., Simshauser, P. \& Nelson, J. 2012, "Queensland solar Feed-in Tariffs and the merit-order effect: economic benefit or regressive taxation and wealth transfers?", Economic Analysis \& Policy, 42(3): 277301. 
Nelson, T., Nelson, J., Ariyaratnam, J. and Camroux, S. 2013, “An analysis of Australia's large scale renewable energy target: restoring market confidence”, Energy Policy, 62(2013): 386-400.

Nelson, T., Reid, C. and McNeill, J. 2015, "Energy-only markets and renewable energy targets: complementary policy or policy collision?”, Economic Analysis \& Policy, 46(2015): 25-42.

NETT: National Emissions Trading Taskforce, 2006, Possible Design for a National Greenhouse Gas Emissions Trading Scheme. NSW Government, Sydney.

Neuhoff, K., Wolter, S. and Schwenen, S. 2016, "Power markets with renewables: new perspectives for the European Target Model”, The Energy Journal, 37(S12): 23-38.

Newbery, D. 2015, "Missing money and missing markets: reliability, capacity auctions and interconnectors", EPRG Working Paper 1508, Energy Policy Research Group, University of Cambridge.

Nicolosi, M. 2012. The economics of renewable electricity market integration. An empirical and modelbased analysis of regulatory frameworks and their impacts on the power market, $\mathrm{Ph} . \mathrm{D}$. thesis, University of Cologne.

Nong, D. and Siriwardana, M. 2017, “Australia's emissions reduction fund in an international context”, Economic Analysis \& Policy, 54(2017): 123-134.

Onifade, T. 2016, "Hybrid renewable energy support policy in the power sector: the contracts for difference and capacity market case study", Energy Policy, 95(2016): 390-401.

Peters, J. and Hertel, T. 2017, “Achieving the Clean Power Plan $2030 \mathrm{CO}_{2}$ Target with the New Normal in Natural Gas Prices”, The Energy Journal, 38(5): 39-66.

Peters, B. 2002, “Governance: a garbage can perspective”, Institute for Advanced Studies, 84 Political Science Series, Vienna. Available at http://aei.pitt.edu/347/1/wp_84.pdf (Accessed September 2017).

Pollitt, M. and Anaya, K. 2016, "Can current electricity markets cope with high shares of renewables? A comparison of approaches in Germany, the UK and the State of New York", The Energy Journal, 37(S12): 69-88.

Price, D. 2017, “The NEM is broken, bring on NEM 2.0", Speech to the Australian British Chamber of Commerce. Frontier Economics, Melbourne. Available at http://www.frontiereconomics.com.au/documents/2017/08/nem-2-0-speech-notes-danny-price.pdf (Accessed August 2017)

Rawat, P. and Morris, J. 2016, "Kingdon's 'streams' model at thirty: still relevant in the $21^{\text {st }}$ century?", Politics \& Policy, 44(4): 608-638.

Samter, M., Wilson, P. \& Prendiville, C. (2017), “Australian east coast gas: the horse, hunter \& stag”, Credit Suisse Equity Research, Sydney, 8 August 2017.

Schelly, C. 2014, "Implementing renewable energy portfolio standards: the good, the bad and the ugly in a two state comparison”, Energy Policy, 67(2014): 543-551.

Simshauser, P. 2010, "Vertical integration, credit ratings and retail price settings in energy-onlymarkets: navigating the Resource Adequacy problem", Energy Policy, 38(2010): 7427-7441.

Simshauser, P. 2011, "The hidden cost of wind generation in a thermal power system: what cost?", Australian Economic Review, 44(3): 269-292.

Simshauser, P. 2014, "From first place to last: the National Electricity Market's policy-induced energy market death spiral", Australian Economic Review, 47(4): 540-562.

Simshauser, P. 2017a, "Monopoly regulation, discontinuity \& stranded assets", Energy Economics, 66(2017): 384-398. 
Simshauser, P. 2017b, “On intermittent renewable generation and the stability of Australia's National Electricity Market”.

Simshauser, P., Nelson, T. \& Doan, T. 2011, "The boomerang paradox, Part I: how a nation's wealth is creating fuel poverty", The Electricity Journal, 24(1): 72-91.

Simshauser, P. and Nelson, T. 2015a, “The Australian east coast gas supply cliff”, Economic Analysis \& Policy, 45(2015): 69-88.

Simshauser, P. and Nelson, T. 2015b, "Australia's coal seam gas boom and the LNG entry result", The Australian Journal of Agricultural and Resource Economics, 59(2015): 602-623.

Tiernan, A. and Burke, T. 2002, "A load of old garbage: applying garbage-can theory to contemporary housing policy", Australian Journal of Public Administration, 61(3): 86-97.

Wagner, L. Molyneaux, L. and Foster, J. 2014, “The magnitude of the impact of a shift from coal to gas under a carbon price”, Energy Policy, 66(2014): 280-291.

Wild, P., Bell, W.P. and Foster, J. 2015, "Impact of carbon prices on wholesale electricity prices and carbon pass-through rates in the Australian National Electricity Market", The Energy Journal, 36(3): 137 153.

Wiser, R. and Bolinger, M. 2017. “2016 Wind Technologies Market Report”, Lawrence Berkeley National Laboratory. Available at https://emp.lbl.gov/sites/default/files/2016_wind_technologies_market_report_final_optimized_1.pdf Accessed September 2017. 